NBER WORKING PAPER SERIES

\title{
THE EFFECT OF PROVIDING BREAKFAST ON STUDENT PERFORMANCE: EVIDENCE FROM AN IN-CLASS BREAKFAST PROGRAM
}

\author{
Scott A. Imberman \\ Adriana D. Kugler \\ Working Paper 17720 \\ http://www.nber.org/papers/w17720 \\ NATIONAL BUREAU OF ECONOMIC RESEARCH \\ 1050 Massachusetts Avenue \\ Cambridge, MA 02138 \\ January 2012
}

We would like to thank Steven Craig, Diane Whitmore Schanzenbach, Dietrich Vollrath, employees of an anonymous large urban school district and participants at APPAM and the Stata Texas Empirical Microeconomics Conference for helpful comments and suggestions. (02011 by Scott Imberman and Adriana Kugler. Short sections of text not to exceed two paragraphs may be quoted without permission provided proper citations are made. All errors remain our own. The views expressed herein are those of the authors and do not necessarily reflect the views of the National Bureau of Economic Research. Although Dr. Kugler is currently serving as the Chief Economist with the U.S. Department of Labor, this paper was authored prior to her assuming that position and reflects her personal views and does not purport to reflect the official views of the U.S. Department of Labor.

NBER working papers are circulated for discussion and comment purposes. They have not been peerreviewed or been subject to the review by the NBER Board of Directors that accompanies official NBER publications.

(C) 2012 by Scott A. Imberman and Adriana D. Kugler. All rights reserved. Short sections of text, not to exceed two paragraphs, may be quoted without explicit permission provided that full credit, including (c) notice, is given to the source. 
The Effect of Providing Breakfast on Student Performance: Evidence from an In-Class Breakfast Program

Scott A. Imberman and Adriana D. Kugler

NBER Working Paper No. 17720

January 2012

JEL No. I10,I21

\begin{abstract}
In response to low take-up, many public schools have experimented with moving breakfast from the cafeteria to the classroom. We examine whether such a program increases performance as measured by standardized test scores, grades and attendance rates. We exploit quasi-random timing of program implementation that allows for a difference-in-differences identification strategy. Our main identification assumption is that schools where the program was introduced earlier would have evolved similarly to those where the program was introduced later. We find that in-class breakfast increases both math and reading achievement by about one-tenth of a standard deviation relative to providing breakfast in the cafeteria. Moreover, we find that these effects are most pronounced for low performing, free-lunch eligible, Hispanic, and low BMI students. We also find some improvements in attendance for high achieving students but no impact on grades.
\end{abstract}

Scott A. Imberman

Department of Economics

University of Houston

204 McElhinney Hall

Houston, TX 77204

and NBER

simberman@uh.edu

Adriana D. Kugler

Georgetown University

Georgetown Public Policy Institute

37th and O Streets NW, Suite 311

Washington, DC 20057

and NBER

ak659@georgetown.edu

An online appendix is available at:

http://www.nber.org/data-appendix/w17720 


\section{Introduction}

Malnutrition continues to be a problem in the U.S. due to both undernourishment and obesity, especially among children from disadvantaged backgrounds. Food insecurity is also more prevalent among single-parent and minority households. Moreover, food insecurity has increased with the recent recession, so that nutritional problems are particularly worrisome today (Nord, Coleman-Jensen, Andrews and Carlson, 2010). For example, it is estimated that between $12 \%$ and $35 \%$ of children in the US skip breakfast (Gardner, 2008).

Given the inability of households to solve nutritional deficiencies on their own, ${ }^{2}$ it is not surprising that the link between good nutrition and the capacity of children to learn has long been a concern for policy makers in the United States. Publicly-provided programs to feed children in schools date back to the Great Depression, when the Agricultural Adjustment Act was introduced in 1935. In 1946, school provision of supplemental feeding was institutionalized through the National School Lunch Program (NSLP). In 1966 the Child Nutrition Act added the School Breakfast Program (SBP) as a two-year pilot project to assist "nutritionally needy" children, and the program received permanent authorization in 1975.

Unfortunately, participation in the SBP is low. At most $60 \%$ of students eligible for free breakfast participate in the program (Dahl and Scholz, 2011). This could be due to “time/scheduling conflicts, cafeteria space or the embarrassment associated with eating a free or reduced-price breakfast" (Cullen, 2010). Further, while the intent is for SBP to increase breakfast consumption, it is possible that children with access to a SBP may eat less at home. Waehrer (2008) looks at time-diary data and finds that children in the School Breakfast Program actually consume less on weekdays than weekends suggesting that the program may reduce consumption,

\footnotetext{
${ }^{2}$ This could be either because households face limited access to credit, or because of shortsighted behavior from the part of parents and children.
} 
although it is not clear what the students would have eaten on weekdays in the absence of the program.

Given low take-up of free and reduced-price meals and clinical evidence that breakfast improves cognitive performance (Alaimo, Olson and Frongillo, 1999; Middleman, Emans, and Cox. 1996; Wesnes, Pincock, Richardson, Helm, and Hails, 2003) a number of districts around the country have undertaken school breakfast programs which reduce the time and effort costs to students by moving the meals from cafeterias to the classrooms. School districts in Houston, Dallas, Little Rock, Memphis, Florida's Orange County, Maryland's Prince George's County, and Chicago have all moved breakfast to the classrooms in the hope of giving students, especially those from low-income families, a healthier start to their day. The idea is that having a good meal at the beginning of the day reduces over-eating and obesity, and will increase kids' alertness and their capacity to learn. However, it is also possible that students will "double up" and eat breakfast both at home and at school, which could contribute to obesity. Further, there are concerns that the time it takes to serve and eat the breakfast - usually around 20 minutes reduces instruction time.

In this paper, we study the impact on students' academic performance and attendance from an "in-class breakfast" (ICB) program implemented in a large urban school district in the Southwest United States (LUSD-SW). ${ }^{3}$ This program delivers breakfast directly to classrooms at the start of the day. Providing breakfast in class avoids space and scheduling problems and providing all kids free breakfast avoids embarrassment issues. LUSD first piloted the project in 33 schools and later expanded it to all elementary and middle schools starting on February $2^{\text {nd }}$, 2010 with the roll-out finishing in fall 2010. A nice feature of the roll-out for the purposes of our

\footnotetext{
${ }^{3}$ Researchers seeking access to the data for replication should contact the authors, at which point we will identify the district for the requestors and provide instructions for how to submit a research proposal to the district's research department.
} 
empirical analysis is that the timing of implementation had little to do with school characteristics. While the roll-out was initially aimed such that schools with higher economically disadvantaged rates started first, in practice it did not work out this way. ${ }^{4}$ First, some schools had rollout dates changed to accommodate logistical necessities (i.e. having schools in the same areas start around the same time) or principals' requests. Second, and perhaps more importantly, $65 \%$ of elementary schools in LUSD have economic disadvantage rates of $90 \%$ or higher. As a consequence, during the first 11 weeks of the program rollout, there is remarkably little variation in terms of economically disadvantaged rates and other characteristics of the schools across implementation dates. For example, the mean economic disadvantage rate in week 1 is $94.2 \%$ while the mean in week 11 is $92.0 \%$. This indicates that schools that implemented the program early differed little from later adopters along observable characteristics. ${ }^{5}$ More importantly given our difference-in-differences identification strategy, early and late adopters have virtually no differences in trends.

Using schools that adopt during weeks 1 through 11, a time period that covers the testing days for the $5^{\text {th }}$ grade state exam in week 9 , we assess the impact of providing breakfast in class on achievement, grades and attendance using a difference-in-differences approach. We find that achievement increased in schools that adopted ICB before testing compared to schools where ICB was adopted after testing. In particular, the introduction of breakfast in the classroom increased test scores by 0.1 standard deviations in both reading and math, which is half of the effect of reducing class size from 22 to 15 students in the Tennessee Project STAR experiment

\footnotetext{
${ }^{4}$ A student is considered economically disadvantaged if she qualifies for free-lunch, reduced-price lunch or another Federal or state anti-poverty program.

${ }^{5}$ A small portion of schools in LUSD have relatively low disadvantage rates. These schools mostly began their programs after the $11^{\text {th }}$ week of the roll-out. As a consequence schools that adopted in the $12^{\text {th }}$ week and later differ from those that adopted earlier. Hence, we only consider schools adopting during the first 11 weeks of the program in our analysis.
} 
(Krueger, 1999). Moreover, these effects were larger for students with low pre-program achievement, those who qualified for free lunch, Hispanics, children with limited English proficiency, and students with a low body-mass index (BMI). We also allow for the impact to vary by length of exposure prior to testing. We find little evidence that impacts vary with exposure-time. We also find little evidence that ICB affected grades. The lack of differential impacts by exposure time and dearth of impacts on grades suggest that the program may be helping students perform better on exams but may be less effective in increasing learning. Nonetheless, our evidence only provides suggestive support for this theory as, due to short implementation window, we cannot rule-out longer-term effects of exposure time and the lack of grade impacts could reflect teachers adjusting their grading curves as students improve. Finally, we find some improvements in attendance for high achieving students.

We test the validity of our results in three ways. First we show that the timing of adoption is mostly uncorrelated with school characteristics and changes in those characteristics conditional on the school adopting in the first 11 weeks of implementation. Second, we estimate placebo tests in the spirit of Angrist and Krueger (1999) that estimate the difference in difference "impact" of adoption using only pre-ICB data. This checks for whether underlying trends may be influencing our results. These tests provide little evidence of any such trending. Third, we test whether there are difference-in-differences "impacts" on contemporaneous exogenous covariates and find no significant effects.

\section{Previous Literature}

There is an extensive literature on the link between nutrition and education in the developing country context, but a more limited literature on the nutrition-schooling relationship 
in developed countries. Studies for the developing world often estimate the correlation between nutrition and health on schooling outcomes. The main problem with many of these papers is that factors omitted from these regressions (e.g., parental schooling, family income) are likely associated with both health and schooling of the children. For this reason, studies for Zimbabwe and Pakistan use civil war, drought shocks and price shocks to generate as-good-as random changes in nutritional status (Alderman, Behrman, Lavy and Menon, 2001; Alderman, Hoddinott and Kinsey, 2006). Another study for the Philippines uses panel data and a structural model to identify the effect of nutrition on academic achievement (Glewwe, Jacoby and King, 2001). Only a few papers in the developing country context have been experimental in nature. The best wellknown experimental study is the one by Maluccio et al. (2009) for Guatemala which looks at an early childhood nutritional intervention. This study finds that providing a highly nutritious food supplement increased scores in reading comprehension and non-verbal cognitive ability compared to the less nutritious drink, but there was no control group without a drink in the experiment. ${ }^{6}$ In another paper Vermeersch and Kremer (2004) find that a meals program introduced randomly in 25 pre-schools in Western Kenya increased test scores but only in schools where teachers were relatively experienced prior to the program.

By contrast to studies in the developing world, most research on the effects of nutrition on learning in developed countries has been conducted by physicians and public health experts. ${ }^{7}$ The most credible studies for developed countries have involved experimental trials which randomly assigned kids to receiving breakfast or no breakfast and the following week switch the assignment. This means that each child acts as his/her own control. The best studies include Pollitt, Leibel and Greenfield (1981) and Pollitt, Lewis, Garza and Shulman (1982) who

\footnotetext{
${ }^{6}$ A study for Jamaica by Walker et al. (2005) and a study for Peru by Cueto et al. (1999) also conduct randomized trials that look at the very short run impacts of nutritional supplementation under voluntary participation.

${ }^{7}$ See Rampersaud, Pereira, Girard, Adams and Metzl (2005) for a review.
} 
examined the impact of an overnight and morning fast in two experiments on 9 to 11-year-old children. These studies show that treatment did not affect IQ test scores or results from a continuous performance task examination. While the random assignment of individuals to treatment indicates that these results can be interpreted in a causal manner, there are a number of drawbacks to this approach. First, sample sizes are small. Second, participation in the program is voluntary and thus those participating in the experiment are likely those who will benefit more from it. Most importantly, these experiments look at very short-run effects. Malnutrition is a cumulative process that does not develop from not eating for a day and these experiments considered children who were well-nourished.

Other studies that consider the medium-term effect of nutrition on schooling in the U.S. use non-experimental data and for the most part do simple comparisons of schools participating in the School Breakfast and Lunch programs to non-participating schools. While some of these studies do not control for other school and student characteristics in the participating and nonparticipating schools, others attempt to control for observable differences. However, even controlling for observable differences may not be enough, since schools may self-select into participating in the program on the basis of unobservable characteristics (e.g., local wealth levels). Likewise, other studies compare children eligible for free/reduced price meals to those not eligible, but these students differ on the basis of unobservable characteristics both at the school and student levels. ${ }^{8}$ For example, a study by Meyers et al. (1989) finds that the Massachussetts school breakfast program is associated with higher test scores and lower levels of tardiness and absences, but this study does not control for the selection described above. Dunifon and Kowaleski-Jones (2003) address potential selection into free/reduced price meal eligibility

\footnotetext{
${ }^{8}$ For example, Figlio and Winicki (2005) find that schools change the meals they serve on the basis of whether students are testing on a given week and Anderson and Butcher (2006) find that schools under financial pressure tend to adopt potentially unhealthy food policies.
} 
by comparing children within the same family one of whom attends a school with a school meal program while the other attends a school without a program. While there may still be the problem that parents send the more needy children to a school with a school meal program while sending the other child to a school without a program, this study reports that the likelihood of split participation is not associated with child-specific factors (including health status or BMI). Following this strategy, Dunifon and Kowleski-Jones (2003) find that participation in the NSLP does not predict improved child outcomes. The best non-experimental study for the U.S. is a study by Hinrichs (2010) who exploits differences in eligibility rules across cohorts and states for free/reduced-price lunch. Hinrichs finds that those who participated in the program as children experienced sizable and significant increases in educational attainment. ${ }^{9}$

Our analysis is closest to Hinrichs (2010) in that we conduct a non-experimental analysis exploiting the differential timing in the introduction of the breakfast program in schools in a large urban school district in the Southwest United States to identify the effect of providing breakfast on student performance, including grades and test scores. In addition, we examine the impact on attendance.

\section{The In-Class Breakfast Program}

The LUSD in-class breakfast program provides breakfast to students in their classrooms during the first 15 - 20 minutes of the school-day. Prior to the program, all students were able to get a free breakfast in the school cafeteria before the start of the school day. Students are given an entrée that could be hot or cold (i.e. yogurt, chicken biscuit, pop-tart, mini pancakes, etc.) usually with a snack item (i.e. fruit, blueberry muffin, graham crackers), a juice and milk. On

\footnotetext{
${ }^{9}$ A related line of research examines how school food and nutrition programs affect obesity (Anderson and Butcher. 2006; Hofferth and Curtin. 2005; Schanzenbach, 2009;) and other health outcomes (Bernstein, McLaughlin, Crepinsek, and Daft, 2004; Bhattacharya, Currie and Haider, 2006).
} 
average a student could consume up to 534 calories from the breakfast. This is comparable to the meals offered in the cafeteria where a student could consume up to 520 calories on average. ${ }^{10}$

Hence, while low take-up more generally can be due to stigma, this is unlikely to be the case in LUSD. Thus, we interpret this movement of breakfast from the cafeteria to the classroom as a reduction in the cost to the student of acquiring breakfast in terms of time and convenience since he or she does not need to arrive at school early or walk to the cafeteria. This change in costs may lead to an increase in calorie consumption on average. Unfortunately, we do not have the data to test directly for whether students consume more calories. However, while it is feasible that some students may not change their behavior, it is likely that serving breakfast in the classroom will cause other students to consume more food overall.

LUSD began providing breakfast in class in 2008-09 to a set of 33 pilot schools. LUSD began the ICB program in response to low-uptake of the cafeteria breakfasts. A comparison of the pilot schools to non-pilot schools in the district found that while $80 \%$ of students in the former ate breakfast in school only $41 \%$ of the latter did so as well. ${ }^{11}$

In 2009-10 LUSD started implementing the program in the non-pilot schools. All but a handful of elementary schools started in that year, while the rest of the elementary schools and secondary schools began ICB early in the 2010-11 school-year. Given this timing, we only assess elementary schools in this study. The initial intention was to implement the program in new schools each week starting with the schools with the highest rates of economically disadvantaged students and ending with the lowest. However, in practice the implementation did not occur this

\footnotetext{
${ }^{10}$ Authors' calculations from school menus and nutrition information.

${ }^{11}$ It is not obvious whether this is due to more students eating breakfast who weren't before, since some of the new in-school eaters may have been eating breakfast at home or the difference may reflect selection of schools into the pilot program. Nonetheless, given that principals entered the pilot voluntarily it is likely they did so in response to low in-school consumption, which would imply that this is an underestimate of the actual effect on take-up. Unfortunately, we do not have access to consumption data and hence cannot independently confirm these figures.
} 
way. Adoption dates were modified for a number of logistical reasons such as principal requests for delays or to facilitate food deliveries. This combined with the fact that $65 \%$ of LUSD elementary schools had economic disadvantage rates above $90 \%$ made schools that adopted during the beginning of the 11 week period from February 2, 2010 to April 20, 201 remarkably similar on observable characteristics to those that adopted towards the end of the period. Hence, we argue that the implementation was quasi-random whereby treatment effects are identified in a difference-in-differences framework; that is, we assume that adoption timing during the first 11 weeks of the roll-out is uncorrelated with trends in underlying school characteristics.

Table 1 provides support for this assumption. In this table we provide some characteristics of elementary schools that adopted ICB at different times. New schools implement the program every week starting on the week of February 2, 2010 through September 21, 2010 with some gaps during testing periods and summer break. This table shows that amongst schools that implemented the program from February 2, 2010 through April 20, 2010, the week of adoption is uncorrelated with many observable dimensions, including percent of students economically disadvantaged, black, Hispanic, with Limited English Proficiency, average teacher experience and tenure, student-teacher ratio, and attendance in the 2008-2009 school year. Joint significance tests show that only only per-pupil expenditures and mean achievement significantly differ by week of adoption, however the achievement differences appear to be driven by schools that adopt in week 5 . Indeed, dropping week 5 from the sample reduces the F-statistics to insignificant values of 1.2 and 1.6 for math and reading, respectively. Later we provide specifications excluding week 5 from our analysis and find that our results are unaffected. 
More importantly for our difference-in-differences identification strategy, Panel B of Table 1 shows that the 99 schools where the program was introduced between February 2 and April 20, 2010 do not differ in terms of changes between 2006-07 and 2008-09 in any of the above mentioned characteristics. This suggests that initially the program was introduced in a close to random manner, at least conditional on fixed school characteristics. Later, we further test this assumption through estimates of impacts on exogenous covariates and placebo tests that look for impact estimates using only pre-program data.

\section{Estimation Strategy}

To implement our difference-in-differences strategy, we estimate the following regression to look at the effects of the ICB program on student achievement:

$$
\mathrm{Y}_{\mathrm{ijt}}=\alpha+\beta \text { Post }_{\mathrm{t}} \times \mathrm{ICB}_{\mathrm{j}}+\psi_{\mathrm{j}}+\mathbf{\Omega} \mathbf{X}_{\mathrm{ijt}}+\boldsymbol{\Theta} \mathbf{Z}_{\mathrm{jt}}+\varepsilon_{\mathrm{ijt}}
$$

where $\mathrm{Y}_{\mathrm{ijt}}$ is student test scores, grades, or absenteeism for student $\mathrm{i}$, in school $\mathrm{j}$, at time t. $\mathrm{X}_{\mathrm{ijt}}$ includes race, gender, and indicators for whether the student qualifies for free lunch, reduced price lunch or is otherwise economically disadvantaged, grade fixed-effects and year fixed-

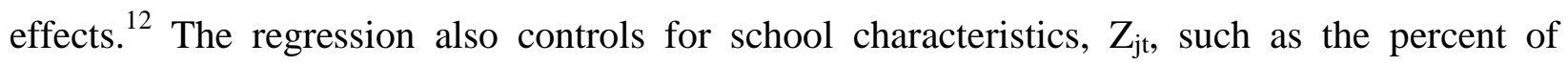
students of each race/ethnicity in the school, economically disadvantaged, of limited English proficiency, in special education, in bilingual education, in each grade level, or referred to an alternative disciplinary program. Moreover, we will include school fixed effects, $\psi_{\mathrm{j}}$, to control

\footnotetext{
${ }^{12}$ A student is considered otherwise disadvantaged if he or she does not qualify for free or reduced-price lunch but does qualify for other Federal or state anti-poverty programs.
} 
for time-invariant unobservable characteristics of the schools, such as the quality of the teachers and principal.

This specification makes our analysis a "difference-in-differences" model where changes in outcomes before and after program implementation for earlier adopters are compared to changes in outcomes for schools that adopt late in the process. The difference-in-differences impact of the program is captured by the estimate for $\operatorname{Post}_{t} \times \mathrm{ICB}_{\mathrm{j}}$ which is an interaction of a dummy for being in a period after the introduction of the program, Post $t_{t}$, with an indicator of whether the school participated in the program up until that point, $\mathrm{ICB}_{\mathrm{j}}$ (i.e., an indicator for whether the ICB was implemented in weeks 1 through 8 ). For test scores, $5^{\text {th }}$ grade students took the state accountability exams in reading and math on April 6 and 7. Hence, for these students, we will estimate equation (1) by comparing schools where ICB started prior to April 6 to those where it started afterwards but before April 27. ${ }^{13}$ Since it is unclear whether schools that implement during the week of April 6 provide the program to $5^{\text {th }}$ grade students due to the testing, we drop all schools that adopt during this week (9) from all of our analyses.

The difference-in-differences framework described above only requires that trends for early adopters do not differ from trends for late adopters. Hence, we argue that the implementation is quasi-random in the sense that it is unrelated to underlying trends. Below, we provide evidence that indicates the program implementation satisfies this assumption.

The difference-in-differences analysis can be extended to include the duration of exposure to the in-class breakfast program, ICB_Duration ${ }_{\mathrm{jt}}$, or intensity of treatment as follows:

$$
\mathrm{Y}_{\mathrm{ijt}}=\alpha+\beta_{1} \text { Post }_{\mathrm{t}} \times \mathrm{ICB}_{\mathrm{j}}+\beta_{2} \mathrm{ICB}_{-} \text {Duration }_{\mathrm{jt}} \psi_{\mathrm{j}}+\mathbf{\Omega} \mathbf{X}_{\mathrm{it}}+\mathbf{\Theta Z}_{\mathrm{jt}}+\varepsilon_{\mathrm{ijt}} .
$$

\footnotetext{
${ }^{13}$ Since $3^{\text {rd }}$ and $4^{\text {th }}$ graders took the exam on the week of April $27^{\text {th }}$, we cannot estimate this model for these students.
} 
After controlling for student characteristics and school characteristics, we may expect for students in schools that have participated longer in the ICB program to have improved nutrition and to have better achievement. On the other hand, it is possible any benefits accrue merely from a "day of testing" effect whereby the extra calories boost concentration on the exam but do little to improve general learning. We will also provide estimates from a more flexible version of model (2) as follows

$$
\mathrm{Y}_{\mathrm{ijt}}=\alpha+\sum_{w} \beta_{w} \text { Post }_{\mathrm{t}} \times \mathrm{ICB}_{-} \mathrm{Week}_{\mathrm{wj}}+\psi_{\mathrm{j}}+\mathbf{\Omega} \mathbf{X}_{\mathrm{it}}+\mathbf{\Theta Z}_{\mathrm{jt}}+\varepsilon_{\mathrm{ijt}}
$$

where $w$ is the week of implementation and $I C B_{-}$Week is an indicator for a school adopting during week $w$. This version of the model allows us to track the impact estimates from week to week as the program is implemented. Finally, since the availability of breakfast is unlikely to affect all students equally, and in particular is likely to have a bigger impact on low-SES students, we provide analyses that split the sample by economic status, ethnicity, gender, LEP status and prior achievement, which will allow us to test whether the impact of the ICB program varies for different types of students. Further, we are able to test for differences in impacts by students' BMI for a subset of schools in 2008-09 and 2009-10. This is important, as ex-ante we would expect breakfast to have a larger impact on undernourished students, for which we use low BMI as a proxy. Note that in the BMI regressions, since we only have two years of data we do not include school fixed-effects.

Since grades and attendance accrue continually, we use modified versions of equations (1) and (2) for these outcomes. Since there are four grading periods and six attendance periods 
during the school-year, in these cases we include grade level-period fixed-effects instead of year fixed-effects as we have both within-year and across-grade variation. This accounts for differences across grades in each time period as well as differences across time periods due to, for example, students becoming restless as the Holidays approach or becoming more likely to skip school as the school-year ends. We consider a school to be treated if it adopts ICB at any point during the grading/attendance period. However, this may be a poor measure of exposure as a student who is exposed to ICB for the full period may be affected more than one who is exposed only for part of the period. Thus our focus is on the duration model in equation (2) but we also estimate the following model:

$$
\mathrm{Y}_{\mathrm{ijt}}=\alpha+\beta_{1} \text { FullyTreated }_{\mathrm{jt}}+\beta_{2} \text { PartiallyTreated }_{\mathrm{jt}}+\psi_{\mathrm{j}}+\mathbf{\Omega} \mathbf{X}_{\mathrm{it}}+\mathbf{\Theta Z}_{\mathrm{jt}}+\varepsilon_{\mathrm{ijt}}(4)
$$

where FullyTreated ${ }_{\mathrm{jt}}$ is an indicator set equal to one if the school is treated for all weeks of

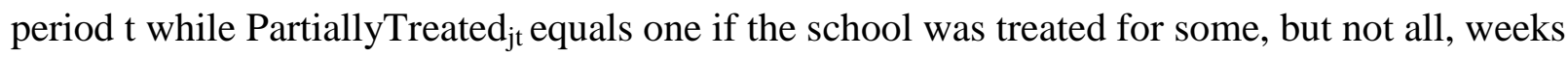
of period t. Both of these values are set to zero in any period prior to implementation.

\section{Data Description}

Our data comes from student records in a large urban school district in the Southwest US (LUSD-SW). The district is one of the largest in the country with over 200,000 students. Given that the program implementation only overlapped with the testing for elementary students, we focus on students in grades 1 to 5. Testing data covers the 2002-03 through 2009-10 academic years, however we start our analysis with 2003-04 in order to allow for the inclusion of lagged achievement in our test-score regressions. For our other outcomes - grades and attendance - the 
data we have is more limited, with only 2008-09 and 2009-10 available for grades and 2009-10 for attendance rates. Further, our data on body mass index is only available in 2008-09 and 200910.

Testing data comes from the state accountability exams in math and reading. These exams are "high stakes" in that the scores determine whether the students are permitted to advance to the next grade as well as the school's accountability rating and whether the school meets "Adequate Yearly Progress" under the No Child Left Behind Act of 2001. Students can take the exam multiple times until they pass. Unfortunately, we do not know whether a given exam score is from the first or a later administration. Hence, we use the student's minimum score in a subject in a given year as their achievement score under the assumption that, since students who fail tend to get extensive coaching for retakes, the lowest score is most likely from the student's first sitting. We then use these scores and standardize them within grade and year across the district. ${ }^{14}$

In addition to achievement the data provides some other student outcomes. In particular we assess the impact of the breakfast program on attendance rates within each six week attendance period in 2009-10 and the student's mean grade across all subjects in each nine week grading period in 2008-09 and 2009-10. ${ }^{15}$ Finally, we have information on student demographics including race, gender, economic status, limited English proficiency, at-risk status, gifted status, and special education, along with BMI data for a subset of schools in 2008-09 and 2009-10. ${ }^{16}$

\footnotetext{
${ }^{14}$ While it is more common to use scale scores in the standardization, unfortunately the state changed the scaling procedure in 2009-10 from a horizontal to a vertical scaling regime making the scale scores in that year incomparable to prior years. Hence, we rely on raw scores for our standardizations.

${ }^{15}$ While it would be interesting to see the impact of the breakfast program on behavior, unfortunately our measure of disciplinary incidents - the number of in-school suspensions or more severe punishments a student receives - is too infrequent in elementary student populations to identify effects.

${ }^{16} \mathrm{~A}$ student is considered at-risk if he or she is low-achieving, has previously been retained, is pregnant or a parent, is LEP, has been placed in alternative education or juvenile detention, is on parole or probation, is homeless, or has previously dropped out of school.
} 
Table 2 provides summary statistics of students in $2009-10$. We limit the sample to the 88 schools that started ICB between February 2 and April 27, 2011 excluding schools that adopt during the week of fifth grade testing (week 9) as it is unclear whether fifth grade students in these schools become treated before or after testing. We then separate our data into three samples for each of the outcome measures we assess - achievement, grades and attendance. As described above, we are limited to fifth grade students for achievement while our data covers grades 1 to 5 for attendance and grades. Nonetheless, the student characteristics are relatively similar across the samples. LUSD is a heavily minority district with $87 \%$ of students being Hispanic or black, but our subsample schools are more heavily minority as only $3 \%$ of students are not black or Hispanic. This is not surprising, given that our subsample is limited to schools with high economic disadvantage rates, as is evidenced in the next row showing that $94 \%$ of students are disadvantaged. Further, a large majority of students are Hispanic rather than black. The schools also have high rates of limited English proficiency. In total, we have 6,353 students and 85 schools in 2009-10 in the achievement sample, 37,309 students in 88 schools in the grades sample and 38,425 students in 88 schools in the attendance sample. Our total estimation sample covers 2003-04 through 2009-10 for achievement, 2008-09 through 2009-10 for grades and 2009-10 only for attendance. They include approximately 40,300 student-year observations for achievement regressions, 286,100 student-grading period observations for grades regressions and 225,900 student-attendance period observations for attendance regressions. 


\section{Effects of In-Class Breakfast on Achievement, Grades and Absenteeism}

\subsection{Effects on Student Achievement}

Table 3 shows the results of regressions using equations (1) and (2) for test scores. Panels A.I and B.I show results from the basic difference-in-differences regressions for math and reading, respectively. Column (1) shows that, on average, the impact of ICP on math and reading is to increase test scores by 0.1 standard deviations in both exams. This is a substantial effect. For comparison, the results are equal to half the impact of reducing class sizes from 22 to 15 students found in the Project STAR experiment (Krueger, 1999). In panels A.II and B.II, we provide estimates that allow the impacts to vary by week of adoption. This specification is useful in determining whether the impacts are due to actual learning gains by students or if the breakfasts are simply increasing students' test-taking performance. If the former is true, then we would expect to see larger achievement impacts for students in early adopting schools than for late adopters. Nonetheless, the estimates in panels A.II and B.II suggest little difference by exposure to treatment. The point estimates on the weeks of exposure interactions with being in the post ICB period are negative, insignificant and close to zero. In Figure 1 we provide graphs that show point estimates and $95 \%$ confidence intervals using equation (3) as the regression model. This figure shows whether any differences by exposure time can be discerned using a less restrictive model. Nonetheless, there is little indication of variation by weeks of exposure. Although somewhat noisy, the week-by-week estimates appear to be centered on 0.1 standard deviations in both subjects throughout the implementation period and show little indication of trending. Thus, the estimates shown here along with those in panels A.II and B.II suggest that the impacts are due to improvements in exam performance but not necessarily from learning itself. ${ }^{17}$

17 Figlio and Winicki (2005) show that schools recognize the potential for extra consumption to improve achievement and thus increase calorie counts of in-school meals during testing weeks. 
Later we provide evidence on course grades that corroborates this. Nonetheless, we caution that the implementation period is only two-months long. Further, a substantial portion of instruction during this period is focused on test preparation specifically. Hence, it is possible that there are learning effects, but they are only detectable over longer time periods.

In rows (2) through (8) of Table 3 we provide estimates that split the samples by the once lagged achievement levels for each student, first by whether the student is above or below the median achievement score and then by the student's achievement quintile. The results indicate that the achievement effects found in Column (1) are primarily coming from students who were low achievers prior to program implementation. For those students who score below the median in the previous year the effects sizes are 0.14 and 0.13 in math and reading, respectively. On the other hand, students who have above median prior achievement have smaller effect sizes of 0.07 and 0.08 in math and reading, respectively with the former being statistically insignificant. Nonetheless, we note that the below and above median estimates do not statistically significantly differ from each other, so we take these results as suggestive rather than conclusive. Similarly, Columns (4) through (8) provide estimates separated by quintiles in which the point estimates for lower quintiles are generally higher than for the upper quintiles. Finally, we also provide estimates that interact treatment status with exposure time for these models in panels A.II and B.II. As with the pooled estimates, there is little to indicate differences by week of adoption. Further, in Figure 2 we repeat the analysis shown in Figure 1 but split the samples by whether the students are above or below median achievers. This figure indicates that the impacts differ little by time of exposure regardless of the students' achievement levels.

In Table 4 we provide results that examine whether there are heterogeneous effects of ICB on different groups of students. Columns (1) and (2) show no differences between boys and 
girls in the effects of the ICB on math and reading test scores. However, when we further split the sample by whether the students are high or low achievers in Columns (3) through (6), the estimates indicate that, while boys on both sides of the achievement distribution are affected similarly, the impacts on girls are heavily concentrated among low achievers. By contrast, the effects on various racial/ethnic groups are clearly different. Columns (7)-(9) show that the ICB increased test scores for Hispanics by 0.14 and 0.15 of a standard deviation in math and reading but had no significant impact on blacks. This is interesting as it indicates that Hispanics were probably more likely to adjust their consumption patterns in response to the breakfast program than black students. Unfortunately, we can only speculate as to the reasons for this racial differential. One possibility is that black students in LUSD are less affected by stigma effects and hence were already eating in the cafeteria prior to program implementation. Another possibility is that LUSD black students are more likely to eat breakfast at home than Hispanic students. ${ }^{18}$ For white students, there are too few observations for reasonable precision in the estimates. Finally, Columns (10) and (11) show that, not surprisingly given the results for Hispanics, students with limited English proficiency also benefit more than non-LEP students. ${ }^{19}$

In Columns (12) and (13) we examine differences in economic status. Unfortunately, since we have so few students in the sample who are not economically disadvantaged we cannot analyze differences along this dimension. Instead we split the sample between those eligible and not eligible for free meals. This effectively separates the sample by those students from families with incomes below $130 \%$ of the Federal poverty line (eligible) and those above that income

\footnotetext{
${ }^{18}$ Another potential explanation is that Hispanics are more likely to be underweight and hence have a higher treatment effect. This is unlikely given that in the BMI sample, $8 \%$ of Hispanics have low BMI compared to $12 \%$ of blacks. Nonetheless, to test this we estimate models using the BMI sample that control for BMI on each of the ethnic subsamples. The results are nearly identical regardless of whether BMI is controlled for, further indicating that this is unlikely to be the explanation. Results are available by request.

${ }^{19} \mathrm{We}$ also investigate differences within sub-groups by high and low achievers. Unlike the gender results, there is little evidence of differences by achievement for the other estimates provided in Table 4 . These results are provided in Online Appendix Table 4.
} 
level (not eligible). The results suggest ICB program has a bigger effect on math test scores for those who are eligible but there are no differences in reading test scores.

Finally, in Columns (14) through (17) we look at whether impacts differ by body mass index. The BMI levels for each student come from height and weight taken during physical fitness tests at the end of the 2008-09 school-year. Unfortunately, the BMI data is only available for a subset of $5^{\text {th }}$ grade schools. ${ }^{20}$ Further, since we only have one pre and one post-adoption period for this analysis we do not include school fixed-effects.

Since the relationship between BMI and obesity differ by age for children we classify the students into four categories based on the Centers for Disease Control's BMI-for-age values and the student's age in months. The four categories are low BMI (children are below the $25^{\text {th }}$ percentile of weight during the CDC base year), medium weight $\left(25^{\text {th }}\right.$ to $84^{\text {th }}$ percentile), overweight ( 85 to $94^{\text {th }}$ percentile) and obese ( $\geq 95^{\text {th }}$ percentile). Note that the first two categories are not the same as those used by the CDC which are underweight $\left(<10^{\text {th }}\right.$ percentile $)$ and healthy weight $\left(10^{\text {th }}\right.$ to $84^{\text {th }}$ percentile). We make this change since we have very few observations that would be classified as underweight.

The results are suggestive that in-class breakfast has a larger positive impact on children with low BMI. In particular, we find that math scores are marginally significantly higher for these students. However, while the point estimate is large at 0.26 standard deviations, the small sample size makes it very noisy. For reading the result is similar but statistically insignificant. For all other weight categories the estimates are much smaller and statistically insignificant.

In Tables 5 and 6 we provide two tests of the validity of our difference-in-differences identification strategy. First, in Table 5 we examine the possibility that schools that adopted prior

\footnotetext{
${ }^{20}$ There is a small relationship between the likelihood of a school having BMI data available and being an early adopter. In particular, schools that adopt prior to week 10 are 8 percentage points more likely to have BMI data available than those that adopt in weeks 10 or 11 . This relationship is significant at the $10 \%$ level.
} 
to the $9^{\text {th }}$ week had pre-existing trends. To test for these trends we conduct a placebo test where we estimate equations (1) and (2) on the sample prior to 2009-10 and label 2007-08 and 2008-09 as the post-period. If there are pre-existing trends then we should expect to see a significant "impact" on achievement for schools that adopt prior to testing in the 2007-08 to 2008-09 period relative to the 2003-04 through 2006-07 period. To further buttress our strategy, we remove school fixed-effects and controls from the regressions. Results with these included are similar and provided in Online Appendix Table 2. The estimates in Table 5 show little to suggest the existence of pre-trends. In all cases - full sample, split by above/below median, and split by quintile - the point estimates on the Post*Treated and Post*Exposure Time variables are statistically insignificant.

Another concern is that if the timing of program implementation is related to changes in the characteristics of students in the adopting schools or if the program changed the composition of the students who tested, our results could be biased. Hence, in Table 6 we provide estimates of the difference-in-differences "impacts" on observable characteristics. Since program adoption is a school-wide event, we aggregate the variables to school-wide means in panel A and $5^{\text {th }}$ grade means in panel B. Nonetheless, student-level analyses show very similar results and are provided in Online Appendix Table 3. ${ }^{21}$ Panel A of Table 6 shows that earlier adoption of the program had no statistically significant effects on students' gender, race, economic disadvantage, LEP status, at-risk status, gifted status, special education status, and most importantly mean lagged reading or math scores. In Panel B, we show the same results emerge if we limit to $5^{\text {th }}$ grade students, with the exception of a marginally significant estimate for LEP.

\footnotetext{
${ }^{21}$ The appendix table also shows that there are no significant impacts on the likelihood of being in a given lagged achievement quintile.
} 
It is instructive to note here that the main effects for being a school treated prior to week 10 do show some small but significant differences in student characteristics. In particular, schools that adopt in weeks 1 through 8 have 3 percentage points more economically disadvantaged students, achievement scores approximately one tenth of a standard deviation lower, lower gifted rates and higher special education rates. This is the primary reason why we argue that the adoption timing is quasi-random rather than entirely random and hence we rely on a difference-in-differences strategy rather than a simple OLS comparison. Nonetheless, the important take-away from this table is that there is little evidence that the changes in achievement found in Table 3 are correlated with contemporaneous changes in student characteristics.

In Table 7, we provide a set of specification checks for our baseline treatment effect estimates. In row (1) we estimate models with lagged achievement omitted. In row (2) we exclude schools that implement the program in week 5 since in Table 1 it appears that week 5 schools have higher 2008-09 achievement scores. In row (3) we exclude schools that implement in week 2 since in panel B of Table 1 we see some indication that these schools have larger changes in achievement prior to adoption. In row (4) we limit the sample only to 2007-08 and later years. In row (5) we provide estimates without school fixed effects. In all of these cases, the point estimates remain very robust for reading. For math the estimates become insignificant in some specifications. Nonetheless, the point estimates remain positive in all cases and do not fall below 0.06 standard deviations. Lastly, in row (6) we provide exposure time estimates for students in $4^{\text {th }}$ grade. Since the exam for $4^{\text {th }}$ grade students occurs after week 11 we cannot estimate overall treatment effects. Nonetheless, we can use the variation in time of exposure to see if these estimates are consistent with our estimates for $5^{\text {th }}$ grade students. Indeed, that is what 
we find, as there appears to be no relationship between time of exposure to ICB and achievement.

\subsection{Effects on Absenteeism and Grades}

Since the advocates of moving breakfast to the classroom often argue that this kind of program helps to reduce tardiness and absenteeism we also look at attendance rates. ${ }^{22}$ Unlike the testing regressions, in these analyses along with the assessments of grades we have access to data for grades 1 through 5 and hence we can see if any impacts arise for younger students. Note that these estimation models do not contain lagged dependent variables. Further, the attendance results are limited only to the 2009-10 school-year since we do not have attendance rates by attendance period in prior years. Hence, we use differences in timing of implementation across attendance periods within 2009-10 - ICB was implemented during attendance periods 4, 5 and 6 - to identify treatment effects.

The results for attendance are provided in Table 8 . We estimate three types of models. The first is a corollary to equation (1) where we include an indicator for whether ICB is in place at any point during period $t$. In Panel II, we modify the analysis to allow for separate estimates for being fully or partially treated as described in Section 4. Finally, in Panel III we estimate models based on equation (2) where the treatment effect is allowed to vary by weeks of exposure.

In general, we find only weak evidence of impacts on absenteeism. When using the full sample in Column (1) we see no significant effect of ICB exposure on attendance rates in any of the three models. When we split by high and low achievers in Columns (2) and (3) we do find some evidence of improvements for high achievers as those who were fully exposed to the

\footnotetext{
${ }^{22}$ Unfortunately, we do not have tardiness data.
} 
program for the entire attendance period saw improvements of 0.25 percentage points or about one-half of a day in a 180 day school year. ${ }^{23}$ In Panel III, we find that an additional week of exposure increases attendance amongst high achievers by 0.07 percentage points. Nonetheless, there is no effect on low achievers. Finally, in Columns (4) to (8) we split the sample by grade level and find little evidence of differential effects by grade level.

Table 9 provides results for average course grades. Once again our data is more limited in years of coverage as the grades data is only available from 2008-09 through 2009-10. Nonetheless, these data provide us eight grading periods over the two years with ICB being implemented during the $3^{\text {rd }}$ and $4^{\text {th }}$ grading period of 2009-10. Using models that mirror those in Table 8 , the results suggest there is little impact of the program on grades. In all three models there are no statistically significant estimates overall, split by achievement level, and split by grade level. One possible explanation for the lack of impact on grades despite the impact on achievement is that since grades have a relative component, teachers may simply adjust their grades to the new, higher performance of the students. On the other hand, the lack of effects here are consistent with finding no exposure time gradient on achievement in that they may reflect the program impacting test performance but not overall learning.

\section{Conclusion}

Concerns about food insecurity and malnutrition amongst students have led education officials to seek out ways to improve nutrition in schools. One increasingly popular strategy is to provide free breakfast to students in the classroom so that students do not need to get to school early to acquire breakfast from the cafeteria. Such programs also have the potential to increase breakfast consumption over cafeteria-based programs as they reduce the potential for stigma

\footnotetext{
${ }^{23}$ This analysis is limited to grades 4 and 5 since testing begins in grade 3.
} 
associated with students going to the cafeteria for breakfast being identified by other students as low-income.

In this paper, we assess the impact of moving breakfast services from the cafeteria to the classroom on student achievement, attendance and grades. Since such a program reduces the time and effort costs to students from consuming breakfast, it is likely that these programs increase consumption. We use data from a large urban school district in the Southwest United States (LUSD) that phased-in an in-class breakfast (ICB) program quasi-randomly over the course of two months in 2010. Since the phase-in period overlaps with $5^{\text {th }}$ grade achievement testing, we are able to identify the impact of the program on math and reading achievement. Using a difference-in-differences strategy we find that providing free breakfast in the classroom increases math and reading achievement by 0.1 standard deviations relative to providing free breakfast in the cafeteria. These effects almost entirely come from Hispanic students, with black students showing little impact. Further, the effects are concentrated in students with low prior achievement. We also find suggestive evidence that the benefits are concentrated in students with low body mass indices.

Since we cannot identify which students switch from not eating breakfast to eating breakfast, one should interpret this intention-to-treat effect as a lower-bound estimate of the actual treatment effect of consuming more food prior to school. To get an idea of the treatment effect, we can use results from a non-randomized pilot study by the school district that found schools that implemented ICB had twice the consumption rate of schools that did not participate in the pilot. At face value this indicates treatment effects are likely on the order of 0.2 standard deviations, however this estimate should be used with caution due to the non-randomness of the pilot. 
We also look at whether impact estimates vary by length of exposure. If the breakfast program increases learning then we would expect to see schools that adopt earlier to have larger impacts than those that adopt later. Our results show little evidence of differences by adoption timing. This suggests that the estimates may reflect "day of testing" effects whereby achievement is improved by extra consumption on testing days (Figlio and Winicki, 2005), although we caution that since the implementation period is short-term we cannot rule out that exposure time effects would emerge over longer time periods.

Finally, we also look at whether the breakfast program affects attendance rates and grades. While we find some evidence that attendance improves amongst high achieving students, we find little evidence of any impacts on grades. This provides further evidence that the achievement gains might be due to better test performance rather than learning gains.

\section{References}

Alderman, Harold, Jere R. Behrman, Victor Lavy and Rekha Menon. 2001. "Child Health and School Enrollment: A Longitudinal Analysis.” Journal of Human Resources, 36(1): 185-205.

Alderman, Harold, John Hoddinott and Bill Kinsey. 2006. "Long Term Consequences of Early Childhood Malnutrition.” Oxford Economic Papers, 58(3): 450-474.

Alaimo, Katherine, Christine Olson and Edward Frongillo. 1999. "Food Insufficiency and American School-Aged Children's Cognitive, Academic and Psychosocial Development," Pediatrics, 108(1): 44-53.

Angrist, Joshua and Alan Krueger. 1999. "Empirical Strategies in Labor Economics," Handbook of Labor Economics, 3A: 1277-1366.

Anderson, Patricia and Kristin Butcher. 2006. "Reading, Writing, and Refreshments: Are School Finances Contributing to Children's Obesity?” Journal of Human Resources, 41: 467-494.

Bernstein, Lawrence, Joan McLaughlin, Mary Kay Crepinsek, and Lyann Daft. 2004. "Evaluation of the School Breakfast Program Pilot Project: Final Report" Nutrition Assistance Program Report Series, No. CN-04-SBP. Alexandra, VA: US Department of Agriculture. 
Bhattacharya, Jayanta, Janet Currie and Steven Haider. 2006. "Breakfast of Champions? The School Breakfast program and the Nutrition of Children and Families," Journal of Human Resources, 41(3): 445-466.

Cullen, Karen. 2010. "HISD Breakfast Program Aids Student Achievement." Houston Chronicle, February 17.

Dahl, Molly W. and John Karl Scholz. 2011. "The National School Lunch Program and School Breakfast Program: Evidence on Participation and Noncompliance." University of Wisconsin, mimeo.

Dunifon, Rachel and Lori Kowaleski-Jones. 2003. "The Influences of Participation in the National School Lunch Program and Food Insecurity on Child Well-Being," Social Service Review, 77(1): 72-92.

Figlio, David and Joshua Winicki. 2005. "Food for Thought: the Effects of School Accountability Plans on School Nutrition," Journal of Public Economics, 89(2-3): 381-394.

Glewwe, Paul, Hanan Jacoby and Elizabeth King. 2001. "Early Childhood Nutrition and Academic Achievement: A Longitudinal Analysis," Journal of Public Economics, 81(3): 345368.

Hinrichs, Peter. 2010. "The Effects of the National School Lunch Program on Education and Health," Journal of Policy Analysis and Management, 29(3): 479-505.

Hofferth, Sandra and Sally Curtin. 2005. "Poverty, Food Programs and Childhood Obesity," Journal of Policy Analysis and Management, 24: 703-726.

Krueger, Alan. 1999. “Experimental Estimates of Education Production Functions.” Quarterly Journal of Economics 114(2): 497-532.

Maluccio, John A., John Hoddinott, Jere R. Behrman, Reynaldo Martorell, Agnes R. Quisumbing and Aryeh D. Stein. 2009. "The Impact of Improving Nutrition During Early Childhood on Eduaction among Guatamalan Adults." Economic Journal 119(537): 734-763.

Meyers, Alan, Amy Sampson, Micahel Weitzman, Beatrice Rogers, and Herb Kayne. 1989. "School Breakfast Program and School Performance," American Journal of Diseases of Children, 143(10): 1234-1239.

Middleman, A.B., S.J. Emans, and J. Cox. 1996. "Nutritional Vit B12 Deficiency and Folate Deficiency in an Adolescent Patient Presenting with Anemia, Weight Loss, and Poor School Performance," Journal of Adolescent Health 19(1): 76-79.

Nord, Mark, Alisha Coleman-Jensen, Margaret Andrews and Steven Carlson. 2010. "Household Food Security in the United States, 2009.” USDA Economic Research Report No. 108. 
Pollitt, Ernesto, Rudolph L. Leibel and Daryl Greenfield. 1981. "Brief Fasting, Stress and Cognition in Children.” American Journal of Clinical Nutrition, 34: 1526-1533.

Pollitt, Ernesto, Nita L. Lewis, Cutberto Garza and Robert J. Shulman. 1982. "Fasting and Cognitive Function.” Journal of Psychiatric Research 17(2): 169-174.

Rampersaud, Gail C., Mark A. Pereira, Beverly L. Girard, Judi Adams, and Jordan D. Metzl. 2005. "Breakfast Habits, Nutritional Status, Body Weight and Academic Performance in Children and Adolescents." Journal of the American Dietetic Association 105(5): 743-760.

Schanzenbach, Diane Whitmore. 2009. "Do School Lunches Contribute to Childhood Obesity?" Journal of Human Resources, 44: 684-709.

Vermeersch, Christel and Michael Kremer. 2004. "School Meals, Educational Achievement and School Competition: Evidence from a Randomized Evaluation," World Bank Policy Research Working Paper No. 3523.

Waehrer, Geetha M. 2008. "The School Breakfast Program and Breakfast Consumption." Institute for Research on Poverty Discussion Paper No. 1360-08.

Wesnes, Keith, Claire Pincock, David Richardson, Gareth Helm, and Simon Hails. 2003. "Breakfast Reduces Declines in Attention and Memory over the Morning in Schoolchildren," Appetite, 41: 329-331. 


\section{Figure 1: Impact of In-Class Breakfast on Achievement By Week of Implementation}
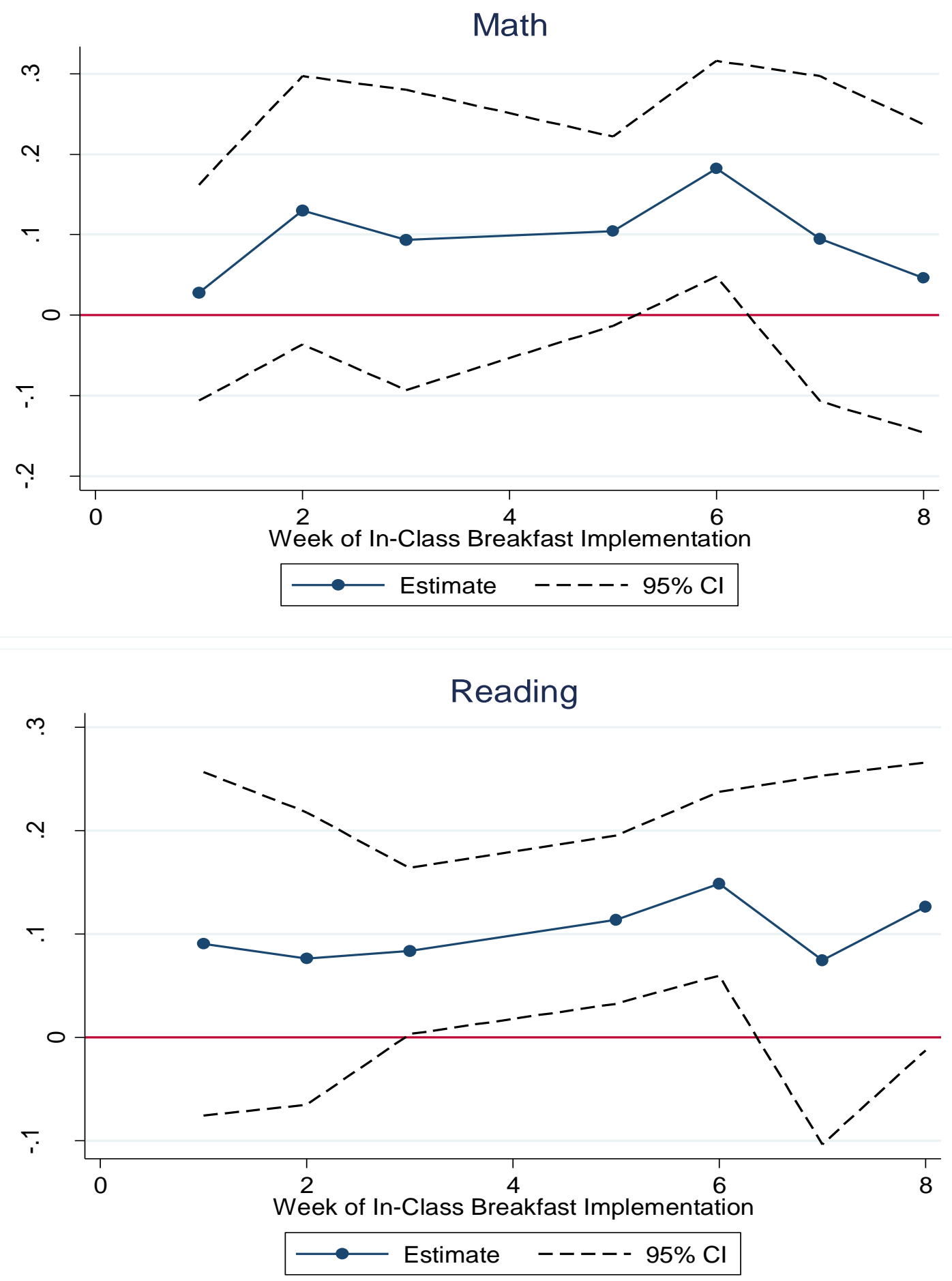

Graphs show point estimates and confidence intervals from regressions of program impact on achievement where the impact estimates are allowed to vary by week of implementation. 
Figure 2: Impact of In-Class Breakfast on Achievement

By Prior Achievement and Week of Implementation
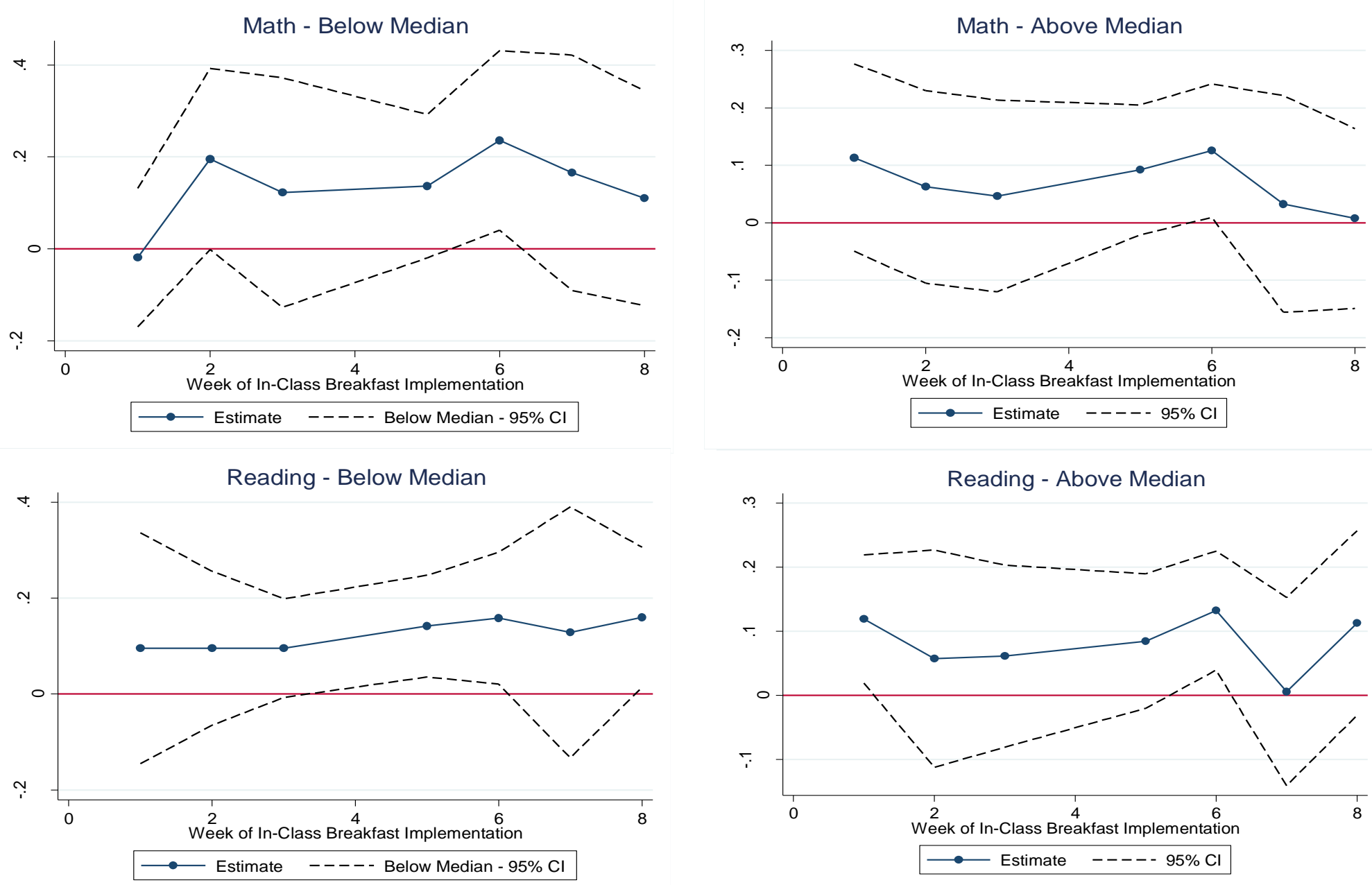

Graphs show point estimates and confidence intervals from regressions of program impact on achievement where the impact estimates are allowed to vary by week of implementation. Samples are split for each exam by whether the student is above or below the median score on the 2008-09 achievement exam. 
Table 1: Means of Elementary School Characteristics by Week of Implementation of In-Class Breakfast

\begin{tabular}{|c|c|c|c|c|c|c|c|c|c|c|c|c|c|}
\hline Week & Start Date & Important Events & $\begin{array}{c}\text { \# of } \\
\text { Schools }\end{array}$ & $\begin{array}{c}\% \text { Econ } \\
\text { Disadv } \\
(1) \\
\end{array}$ & $\begin{array}{c}\text { \% Black } \\
\text { (2) }\end{array}$ & $\begin{array}{c}\text { \% Hisp } \\
\text { (3) }\end{array}$ & $\begin{array}{c}\text { \% LEP } \\
(4) \\
\end{array}$ & $\begin{array}{c}\text { Avg. } \\
\text { Teacher Exp } \\
\text { (years) } \\
(5) \\
\end{array}$ & $\begin{array}{c}\text { Student- } \\
\text { Teacher } \\
\text { Ratio } \\
(6) \\
\end{array}$ & $\begin{array}{c}\text { Attendance } \\
\text { Rate } \\
(7) \\
\end{array}$ & $\begin{array}{c}\text { Per-Pupil } \\
\text { Exp } \\
(8) \\
\end{array}$ & $\begin{array}{c}\text { Mean Math } \\
\text { Achievement } \\
(9) \\
\end{array}$ & $\begin{array}{c}\text { Mean Reading } \\
\text { Achievement } \\
(10) \\
\end{array}$ \\
\hline \multicolumn{14}{|c|}{ A. Levels in 2008-09 } \\
\hline 1 & 2/2/2010 & \multirow{4}{*}{ End of 4th Attendance Period } & 9 & 94.2 & 23.4 & 73.7 & 52.6 & 11.6 & 16.9 & 96.5 & 6787 & -0.16 & -0.21 \\
\hline 2 & 2/9/2010 & & 10 & 94.7 & 32.2 & 66.3 & 40.8 & 10.1 & 16.7 & 96.6 & 7195 & -0.07 & -0.10 \\
\hline 3 & $2 / 16 / 2010$ & & 5 & 96.7 & 31.8 & 67.6 & 44.8 & 11.3 & 16.7 & 97.3 & 7003 & 0 & 0.02 \\
\hline 5 & $3 / 2 / 2010$ & & 12 & 95.2 & 22.9 & 74.5 & 48.5 & 11.1 & 16.2 & 96.7 & 7031 & $-0.23^{* *}$ & $-0.21 * *$ \\
\hline 6 & $3 / 9 / 2010$ & \multirow[t]{3}{*}{ End of 3rd Grading Cycle } & 13 & 94.9 & 33.5 & 65.1 & 43.6 & 10 & 16 & 97.3 & 7636 & -0.07 & -0.09 \\
\hline 7 & $3 / 23 / 2010$ & & 10 & 94.7 & 34.3 & 64 & 40.4 & 12.5 & 16.1 & 96.8 & 7091 & -0.03 & -0.08 \\
\hline 8 & $3 / 30 / 2010$ & & 10 & 94.5 & 36.0 & 62.7 & 41.7 & 12.1 & 15.2 & 97.2 & 7185 & 0.01 & -0.00 \\
\hline 9 & $4 / 6 / 2010$ & \multirow[t]{3}{*}{$\begin{array}{l}\text { 5th Grade Testing, End of 5th } \\
\text { Attendance Period }\end{array}$} & 10 & 90.1 & 29.9 & 68.7 & 44.5 & $9.3 * *$ & 16.8 & 97.2 & 6588 & 0.10 & 0.06 \\
\hline 10 & $4 / 13 / 2010$ & & 10 & 92.9 & 18.1 & 78.3 & 52.4 & $11.9^{* *}$ & 15.8 & 97.2 & 6933 & 0.04 & -0.05 \\
\hline \multirow[t]{2}{*}{11} & $4 / 20 / 2010$ & & 10 & 92.0 & 28.0 & 65.6 & 50.9 & 11.8 & $16.9^{*}$ & 97.1 & 6625 & -0.02 & -0.02 \\
\hline & $4 / 27 / 2010$ & \multicolumn{2}{|l|}{ 3rd \& 4th Grade Testing } & & & & & & & & & & \\
\hline \multicolumn{4}{|c|}{ Joint F-Test for Weeks 2 - 11 (F-statistics; Week 1 Omitted Category) } & 0.7 & 0.4 & 0.3 & 0.5 & 1.3 & 1.4 & 1.2 & $2.1 * *$ & $2.1 * *$ & $2.2 * *$ \\
\hline 12 & $5 / 4 / 2010$ & & 9 & $88.2 * *$ & 15.6 & 78.1 & 48.4 & 12.7 & 16.6 & 97.4 & $6974 *$ & 0.11 & 0.07 \\
\hline 13 & $5 / 11 / 2010$ & & 10 & $70.1 * * *$ & $37.3 * *$ & $44.0^{* * * *}$ & $29.7 * *$ & 13.4 & $15.7 * *$ & $96.5^{* * * *}$ & 7100 & -0.01 & 0.09 \\
\hline 14 & $5 / 17 / 2010$ & & 10 & $57.1 * *$ & $17.0^{* *}$ & 50.3 & 30.1 & 11.3 & $16.5^{*}$ & $97.1 * *$ & $6415^{* * *}$ & 0.13 & 0.18 \\
\hline 15 & $9 / 14 / 2010$ & & 10 & $22.6^{* * * *}$ & $9.1^{*}$ & $25.8 * * *$ & $12.3^{* * * *}$ & $14.0^{*}$ & 17.3 & 97.3 & 6300 & $0.50^{* * *}$ & $0.53 * * *$ \\
\hline 16 & $9 / 21 / 2010$ & & 1 & - & - & - & - & - & - & - & - & & \\
\hline \multicolumn{14}{|c|}{ B. Changes From 2006-07 Through 2008-09 } \\
\hline 1 & 2/2/2010 & & 9 & 0.5 & -2.0 & 1.7 & 4.5 & 0.39 & -0.38 & 0.07 & 928 & -0.05 & -0.10 \\
\hline 2 & 2/9/2010 & & 10 & 1.8 & -1.2 & 0.6 & 1.9 & -0.19 & -0.31 & -0.02 & 1306 & $0.12 *$ & $0.09 * *$ \\
\hline 3 & $2 / 16 / 2010$ & \multirow[t]{2}{*}{ End of 4th Attendance Period } & 5 & 0.1 & -0.9 & 1.0 & 4.0 & 0.83 & -0.35 & $0.52 * *$ & 1095 & -0.03 & -0.02 \\
\hline 5 & $3 / 2 / 2010$ & & 12 & 1.3 & -0.7 & 1.0 & 2.9 & 0.77 & 0.06 & 0.36 & 1131 & -0.02 & -0.01 \\
\hline 6 & $3 / 9 / 2010$ & \multirow[t]{3}{*}{ End of 3rd Grading Cycle } & 13 & 0.5 & 0.0 & 0.2 & 1.8 & 0.73 & 0.05 & 0.49 & 1155 & 0.04 & 0.02 \\
\hline 7 & $3 / 23 / 2010$ & & 10 & 1.9 & -1.4 & 2.0 & 3.7 & -0.14 & $-0.95^{*}$ & 0.33 & 930 & 0.15 & 0.10 \\
\hline 8 & $3 / 30 / 2010$ & & 10 & 2.0 & -3.3 & 4.4 & 5.3 & 0.13 & -0.88 & 0.44 & 1034 & -0.02 & -0.04 \\
\hline \multirow{2}{*}{9} & $4 / 6 / 2010$ & \multirow{4}{*}{$\begin{array}{l}\text { 5th Grade Testing, End of 5th } \\
\text { Attendance Period }\end{array}$} & 10 & & & & & & & & & & \\
\hline & $4 / 0 / 2010$ & & & -0.3 & -0.9 & 1.6 & 2.4 & -0.53 & -0.06 & 0.21 & 846 & 0.05 & 0.01 \\
\hline 10 & $4 / 13 / 2010$ & & 10 & 1.4 & -0.2 & 0.3 & 3.4 & $0.76^{*}$ & -0.48 & 0.35 & 942 & 0.10 & 0.02 \\
\hline \multirow[t]{2}{*}{11} & $4 / 20 / 2010$ & & 10 & 2.1 & -1.9 & 1.8 & 2.8 & 0.43 & -0.00 & 0.33 & 964 & 0.04 & 0.04 \\
\hline & $4 / 27 / 2010$ & \multicolumn{2}{|l|}{ 3rd \& 4th Grade Testing } & & & & & & & & & & \\
\hline \multicolumn{4}{|c|}{ Joint F-Test for Weeks 2 - 11 (F-statistics; Week 1 Omitted Category) } & 0.6 & 0.9 & 1.2 & 0.7 & 0.8 & 0.8 & 1.1 & 0.8 & 0.9 & 0.6 \\
\hline 12 & $5 / 4 / 2010$ & & 9 & $-0.9^{* *}$ & -0.8 & 1.4 & 3.3 & 0.06 & 0.12 & 0.23 & 1224 & 0.02 & -0.03 \\
\hline 13 & $5 / 11 / 2010$ & & 10 & $2.5^{* *}$ & 0.0 & 2.7 & 1.9 & 0.91 & 0.23 & 0.40 & 1084 & -0.04 & 0.06 \\
\hline 14 & $5 / 17 / 2010$ & & 10 & -0.1 & -0.7 & 0.5 & 2.5 & 0.16 & 0.11 & 0.11 & 891 & 0.05 & 0.12 \\
\hline 15 & 9/14/2010 & & 10 & -3.1 & -2.0 & 0.7 & 1.4 & 0.81 & 0.02 & 0.02 & 1057 & -0.01 & 0.03 \\
\hline 16 & $9 / 21 / 2010$ & & 1 & - & - & - & - & - & - & - & - & & \\
\hline
\end{tabular}

income assistance programs. 
Table 2: Summary Statistics in 2009-10

\begin{tabular}{|c|c|c|c|c|c|}
\hline \multicolumn{2}{|c|}{$\begin{array}{l}\text { A. 5th Grade Tested Students Only } \\
\text { (Test Sample) }\end{array}$} & \multicolumn{2}{|c|}{$\begin{array}{l}\text { B. All Students in Grades } 1 \text { - } 5 \\
\text { (Grades Sample) }\end{array}$} & \multicolumn{2}{|c|}{$\begin{array}{l}\text { C. All Students in Grades } 1 \text { - } 5 \\
\text { (Attendance Sample) }\end{array}$} \\
\hline Female & $\begin{array}{c}0.49 \\
(0.50)\end{array}$ & Female & $\begin{array}{c}0.48 \\
(0.50)\end{array}$ & Female & $\begin{array}{c}0.48 \\
(0.50)\end{array}$ \\
\hline Black & $\begin{array}{l}0.23 \\
(0.42)\end{array}$ & Black & $\begin{array}{l}0.23 \\
(0.42)\end{array}$ & Black & $\begin{array}{l}0.23 \\
(0.42)\end{array}$ \\
\hline White & $\begin{array}{c}0.02 \\
(0.12)\end{array}$ & White & $\begin{array}{c}0.01 \\
(0.12)\end{array}$ & White & $\begin{array}{c}0.02 \\
(0.12)\end{array}$ \\
\hline Hispanic & $\begin{array}{l}0.74 \\
(0.44)\end{array}$ & Hispanic & $\begin{array}{l}0.74 \\
(0.44)\end{array}$ & Hispanic & $\begin{array}{l}0.73 \\
(0.44)\end{array}$ \\
\hline $\begin{array}{l}\text { Economically } \\
\text { Disadvantaged }\end{array}$ & $\begin{array}{c}0.94 \\
(0.24)\end{array}$ & $\begin{array}{l}\text { Economically } \\
\text { Disadvantaged }\end{array}$ & $\begin{array}{c}0.94 \\
(0.23)\end{array}$ & $\begin{array}{l}\text { Economically } \\
\text { Disadvantaged }\end{array}$ & $\begin{array}{c}0.94 \\
(0.23)\end{array}$ \\
\hline LEP & $\begin{array}{c}0.40 \\
(0.49)\end{array}$ & LEP & $\begin{array}{c}0.54 \\
(0.50)\end{array}$ & LEP & $\begin{array}{l}0.53 \\
(0.50)\end{array}$ \\
\hline At Risk & $\begin{array}{c}0.67 \\
(0.47)\end{array}$ & At Risk & $\begin{array}{c}0.74 \\
(0.44)\end{array}$ & At Risk & $\begin{array}{c}0.74 \\
(0.44)\end{array}$ \\
\hline Gifted & $\begin{array}{l}0.15 \\
(0.35)\end{array}$ & Gifted & $\begin{array}{l}0.13 \\
(0.34)\end{array}$ & Gifted & $\begin{array}{l}0.13 \\
(0.34)\end{array}$ \\
\hline Special Ed & $\begin{array}{c}0.09 \\
(0.29)\end{array}$ & Special Ed & $\begin{array}{c}0.07 \\
(0.26)\end{array}$ & Special Ed & $\begin{array}{c}0.07 \\
(0.26)\end{array}$ \\
\hline 2008-09 Math ${ }^{\dagger}$ & $\begin{array}{l}-0.01 \\
(0.94)\end{array}$ & 2008-09 $\mathrm{Math}^{\dagger}$ & $\begin{array}{l}-0.05 \\
(0.97)\end{array}$ & 2008-09 $\mathrm{Math}^{\dagger}$ & $\begin{array}{l}-0.06 \\
(0.98)\end{array}$ \\
\hline 2008-09 Reading $\dagger$ & $\begin{array}{l}-0.06 \\
(0.95)\end{array}$ & 2008-09 Reading ${ }^{\dagger}$ & $\begin{array}{l}-0.08 \\
(0.97)\end{array}$ & 2008-09 Reading ${ }^{\dagger}$ & $\begin{array}{l}-0.08 \\
(0.97)\end{array}$ \\
\hline 2009-10 Math & $\begin{array}{l}-0.04 \\
(1.01)\end{array}$ & Mean Grade & $\begin{array}{l}83.1 \\
(7.2)\end{array}$ & $\begin{array}{l}\text { Mean Absence Rate } \\
(\%)\end{array}$ & $\begin{array}{c}3.16 \\
(5.22)\end{array}$ \\
\hline 2009-10 Reading & $\begin{array}{l}-0.10 \\
(1.01)\end{array}$ & & & & \\
\hline $\begin{array}{l}\text { Observations } \\
\text { (Student) }\end{array}$ & 6353 & $\begin{array}{l}\text { Observations } \\
\text { (Student-Time } \\
\text { Period; } 4 \text { Periods) }\end{array}$ & 145,203 & $\begin{array}{l}\text { Observations } \\
\text { (Student-Time } \\
\text { Period; } 6 \text { Periods) }\end{array}$ & 230,550 \\
\hline \# of Students & 6,353 & \# of Students & 37,309 & \# of Students & 38,425 \\
\hline \# of Schools & 85 & \# of Schools & 88 & \# of Schools & 88 \\
\hline
\end{tabular}

$\uparrow$ Prior year reading and math have 5908 observations in panel A, 50306 and 50377 observations, respectively for panel B and 77316 and 77424 observations, respectively for panel C. Scores only available for grades 4 - 5 .

Standard deviations in parentheses 
Table 3 - Effect of In-Class Breakfast on 5th Grade Achievement - Including School Fixed Effects and Controls

$\begin{array}{cc}\text { Full Sample } & \begin{array}{c}\text { By Above/Below } \\ \text { Median Lagged }\end{array} \\ \text { Achievement } & \text { By Lagged Achievement Quintiles }\end{array}$

(1)

$\begin{array}{ccccccc}\text { Below } & \text { Above } & \text { Bottom } & \text { Second } & \text { Third } & \text { Fourth } & \text { Top } \\ (2) & (3) & (4) & (5) & (6) & (7) & \text { (8) }\end{array}$

A. Math

I. Reduced-Form Treatment Effect

$\begin{array}{lcccccccc}\text { Post*Treated } & 0.104 * * & 0.144 * * & 0.070 & 0.159 & 0.170^{* *} & 0.036 & 0.114 * & 0.066 \\ & (0.047) & (0.064) & (0.047) & (0.098) & (0.066) & (0.062) & (0.061) & (0.047) \\ \text { Observations } & 40,317 & 21,096 & 19,221 & 7,708 & 8,921 & 8,863 & 8,132 & 6,693\end{array}$

II. Treatment Effect \& Exposure Time

$\begin{array}{rcccccccc}\text { Post*Treated } & 0.120 & 0.220 * * & 0.031 & 0.312 * * & 0.145 & 0.100 & 0.026 & 0.077 \\ & (0.087) & (0.111) & (0.075) & (0.150) & (0.128) & (0.100) & (0.087) & (0.075) \\ \text { Post*Exposure Time (Weeks) } & -0.003 & -0.015 & 0.008 & -0.029 & 0.005 & -0.013 & 0.018 & -0.002 \\ & (0.013) & (0.015) & (0.011) & (0.019) & (0.019) & (0.015) & (0.012) & (0.010) \\ \text { Observations } & 40,317 & 21,096 & 19,221 & 7,708 & 8,921 & 8,863 & 8,132 & 6,693\end{array}$

B. Reading

I. Reduced-Form Treatment Effect

$\begin{array}{ccccccccc}\text { Post*Treated } & 0.106 * * * & 0.129 * * * & 0.083 * * & 0.161 * & 0.101 * * & 0.103 * * & 0.082 & 0.071 \\ & (0.032) & (0.045) & (0.036) & (0.096) & (0.041) & (0.042) & (0.056) & (0.046) \\ \text { Observations } & 40,379 & 21,408 & 18,971 & 7,956 & 8,929 & 8,944 & 8,082 & 6,468\end{array}$

II. Treatment Effect \& Exposure Time

\begin{tabular}{rcccccccc} 
Post*Treated & $0.133^{*}$ & $0.180 *$ & 0.077 & $0.304 *$ & 0.105 & $0.176 * * *$ & 0.023 & 0.029 \\
& $(0.069)$ & $(0.096)$ & $(0.063)$ & $(0.168)$ & $(0.086)$ & $(0.067)$ & $(0.078)$ & $(0.082)$ \\
Post*Exposure Time (Weeks) & -0.005 & -0.010 & 0.001 & -0.027 & -0.001 & -0.014 & 0.012 & 0.008 \\
& $(0.011)$ & $(0.016)$ & $(0.009)$ & $(0.028)$ & $(0.014)$ & $(0.009)$ & $(0.010)$ & $(0.013)$ \\
Observations & 40,379 & 21,408 & 18,971 & 7,956 & 8,929 & 8,944 & 8,082 & 6,468 \\
\hline
\end{tabular}

Data covers the 2003-04 through 2009-10 academic years. Achievement scores are standardized within grade and year. Due to a change in the scaling procedure in 2009-10 we standarize using raw scores. "Treated" is an indicator for whether a school starts ICB prior to the testing week. Student level covariates include student's race/ethnicity, gender, and economic status along with year and grade level dummies. School level covariates include percent of students who are white, black, Hispanic, Native American, Asian, economically disadvantaged, LEP, in vocational education, in special education, gifted, in bilingual education, in each grade level, referred to an alternative disciplinary program, and school fixed-effects. *, **, and *** denote significance at the $10 \%, 5 \%$ and $1 \%$ levels, respectively. 
Table 4: Effect of In-Class Breakfast on 5th Grade Achievement - By Student Characteristics

\begin{tabular}{|c|c|c|c|c|c|c|c|c|}
\hline & \multicolumn{2}{|c|}{ Gender } & \multicolumn{4}{|c|}{ Gender and Prior Achievement } & \multirow[b]{2}{*}{ Black } & \multirow{2}{*}{$\begin{array}{l}\text { Ethnicity } \\
\text { Hispanic }\end{array}$} \\
\hline & Male & Female & \multicolumn{2}{|c|}{ Male } & \multicolumn{2}{|c|}{ Female } & & \\
\hline & (1) & (2) & $\begin{array}{l}\text { Below Median } \\
\text { Lagged } \\
\text { Achievement } \\
\text { (3) }\end{array}$ & $\begin{array}{l}\text { Above Median } \\
\text { Lagged } \\
\text { Achievement } \\
\text { (4) }\end{array}$ & $\begin{array}{l}\text { Below Median } \\
\text { Lagged } \\
\text { Achievement } \\
\text { (5) }\end{array}$ & $\begin{array}{c}\text { Above Median } \\
\text { Lagged } \\
\text { Achievement } \\
(6)\end{array}$ & (7) & $(8)$ \\
\hline & \multicolumn{8}{|c|}{ A. Math } \\
\hline Post*Treated & $\begin{array}{l}0.107 * \\
(0.056)\end{array}$ & $\begin{array}{c}0.100 * * \\
(0.048)\end{array}$ & $\begin{array}{c}0.117 \\
(0.070)\end{array}$ & $\begin{array}{l}0.099 * \\
(0.059)\end{array}$ & $\begin{array}{c}0.163 * * \\
(0.075)\end{array}$ & $\begin{array}{c}0.039 \\
(0.050)\end{array}$ & $\begin{array}{c}0.019 \\
(0.065)\end{array}$ & $\begin{array}{c}0.138 * * * \\
(0.051)\end{array}$ \\
\hline \multirow[t]{2}{*}{ Observations } & 19,971 & 20,346 & 10,288 & 9,683 & 10,808 & 9,538 & 9,424 & 29,594 \\
\hline & \multicolumn{8}{|c|}{ B. Reading } \\
\hline Post*Treated & $\begin{array}{c}0.107 * * * \\
(0.040)\end{array}$ & $\begin{array}{c}0.106 * * * \\
(0.038)\end{array}$ & $\begin{array}{l}0.092 * \\
(0.052)\end{array}$ & $\begin{array}{c}0.105 * * \\
(0.050)\end{array}$ & $\begin{array}{c}0.182 * * * \\
(0.061)\end{array}$ & $\begin{array}{c}0.052 \\
(0.044)\end{array}$ & $\begin{array}{l}-0.051 \\
(0.055)\end{array}$ & $\begin{array}{c}0.152 * * * \\
(0.035)\end{array}$ \\
\hline \multirow[t]{4}{*}{ Observations } & 20,007 & 20,372 & 10,613 & 9,394 & 10,795 & 9,577 & 9,446 & 29,631 \\
\hline & \multicolumn{2}{|c|}{ LEP Status } & \multicolumn{2}{|c|}{ Free Lunch } & \multicolumn{4}{|c|}{ Body Mass Index ${ }^{\dagger}$} \\
\hline & $\begin{array}{l}\text { Not Lep } \\
\text { (10) }\end{array}$ & $\begin{array}{l}\text { LEP } \\
\text { (11) }\end{array}$ & $\begin{array}{l}\text { Not Eligible } \\
\text { (12) }\end{array}$ & $\begin{array}{c}\text { Eligible } \\
\text { (13) }\end{array}$ & $\begin{array}{c}\text { Low Weight } \\
<25 \text { Percentile } \\
(14)\end{array}$ & $\begin{array}{c}\text { Medium Weight } \\
25 \text { - } 84 \text { Percentile } \\
\text { (15) }\end{array}$ & $\begin{array}{c}\text { Overweight } \\
85 \text { - } 94 \text { Percentile } \\
(16)\end{array}$ & $\begin{array}{c}\text { Obese } \\
\geq 95 \text { Percentile } \\
(17)\end{array}$ \\
\hline & \multicolumn{8}{|c|}{ A. Math } \\
\hline Post*Treated & $\begin{array}{c}0.050 \\
(0.048)\end{array}$ & $\begin{array}{c}0.171 * * \\
(0.080)\end{array}$ & $\begin{array}{c}0.055 \\
(0.054)\end{array}$ & $\begin{array}{c}0.135 * * \\
(0.055)\end{array}$ & $\begin{array}{l}0.260 * \\
(0.136)\end{array}$ & $\begin{array}{l}-0.062 \\
(0.068)\end{array}$ & $\begin{array}{c}-0.044 \\
(0.108)\end{array}$ & $\begin{array}{c}0.063 \\
(0.087)\end{array}$ \\
\hline \multirow[t]{2}{*}{ Observations } & 25,089 & 15,228 & 12,918 & 27,399 & 753 & 3,160 & 1,614 & 2,471 \\
\hline & \multicolumn{8}{|c|}{ B. Reading } \\
\hline Post*Treated & $\begin{array}{c}0.070 * * \\
(0.034)\end{array}$ & $\begin{array}{c}0.155 * * \\
(0.068)\end{array}$ & $\begin{array}{c}0.109 * * \\
(0.041)\end{array}$ & $\begin{array}{c}0.102 * * \\
(0.042)\end{array}$ & $\begin{array}{c}0.230 \\
(0.154)\end{array}$ & $\begin{array}{c}0.036 \\
(0.083)\end{array}$ & $\begin{array}{c}0.036 \\
(0.059)\end{array}$ & $\begin{array}{c}0.070 \\
(0.073)\end{array}$ \\
\hline Observations & 25,129 & 15,250 & 12,944 & 27,435 & 755 & 3,164 & 1,614 & 2,473 \\
\hline
\end{tabular}

† BMI data only includes a subset of schools in 2008-09 and 2009-10.

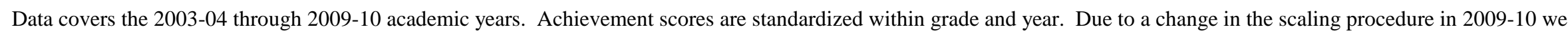

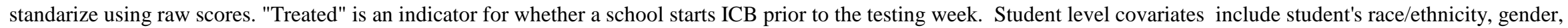
and economic status along with year and grade level dummies. School level covariates include percent of students who are white, black, Hispanic, Native American, Asian, economically disadvantaged, LEP, in vocational education, in special education, gifted, in bilingual education, in each grade level, referred to an alternative disciplinary program, and school fixed-effects. $* * *$, and $* * *$ denote significance at the $10 \%, 5 \%$ and $1 \%$ levels, respectively. 
Table 5: Achievement Placebo Test - Sample Limited to 2008-09 and Earlier and Set 2007-08 and 2008-09 as "Post" Period No Controls or Fixed Effects

\begin{tabular}{|c|c|c|c|c|c|c|c|c|}
\hline & \multirow[t]{2}{*}{ Full Sample } & \multicolumn{2}{|c|}{$\begin{array}{c}\text { By Above/Below } \\
\text { Median Lagged } \\
\text { Achievement }\end{array}$} & \multicolumn{5}{|c|}{ By Lagged Achievement Quintiles } \\
\hline & & Below & Above & Bottom & Second & Third & Fourth & Top \\
\hline & (1) & (2) & (3) & (4) & (5) & (6) & (7) & (8) \\
\hline \multicolumn{9}{|c|}{ A. Math } \\
\hline \multicolumn{9}{|l|}{ I. Reduced-Form Treatment Effect } \\
\hline Post*Treated & $\begin{array}{c}0.006 \\
(0.043)\end{array}$ & $\begin{array}{c}0.056 \\
(0.064)\end{array}$ & $\begin{array}{c}-0.015 \\
(0.045)\end{array}$ & $\begin{array}{c}0.089 \\
(0.095)\end{array}$ & $\begin{array}{l}-0.007 \\
(0.071)\end{array}$ & $\begin{array}{c}0.054 \\
(0.059)\end{array}$ & $\begin{array}{l}-0.031 \\
(0.055)\end{array}$ & $\begin{array}{l}-0.009 \\
(0.044)\end{array}$ \\
\hline Treated & $\begin{array}{l}-0.025 \\
(0.055)\end{array}$ & $\begin{array}{c}0.011 \\
(0.054)\end{array}$ & $\begin{array}{c}0.027 \\
(0.047)\end{array}$ & $\begin{array}{l}-0.020 \\
(0.057)\end{array}$ & $\begin{array}{c}0.056 \\
(0.059)\end{array}$ & $\begin{array}{c}0.030 \\
(0.061)\end{array}$ & $\begin{array}{c}0.002 \\
(0.042)\end{array}$ & $\begin{array}{c}0.024 \\
(0.049)\end{array}$ \\
\hline Observations & 34,506 & 17,946 & 16,463 & 6,537 & 7,595 & 7,585 & 6,974 & 5,718 \\
\hline \multicolumn{9}{|c|}{ II. Treatment Effect \& Exposure Time } \\
\hline Post*Treated & $\begin{array}{c}-0.031 \\
(0.063)\end{array}$ & $\begin{array}{l}-0.015 \\
(0.104)\end{array}$ & $\begin{array}{c}-0.007 \\
(0.066)\end{array}$ & $\begin{array}{c}0.056 \\
(0.168)\end{array}$ & $\begin{array}{c}-0.106 \\
(0.099)\end{array}$ & $\begin{array}{c}-0.047 \\
(0.095)\end{array}$ & $\begin{array}{l}-0.046 \\
(0.078)\end{array}$ & $\begin{array}{c}0.054 \\
(0.068)\end{array}$ \\
\hline Post*Exposure Time (Weeks) & $\begin{array}{c}0.007 \\
(0.009)\end{array}$ & $\begin{array}{c}0.010 \\
(0.015)\end{array}$ & $\begin{array}{c}-0.001 \\
(0.010)\end{array}$ & $\begin{array}{c}0.002 \\
(0.026)\end{array}$ & $\begin{array}{c}0.018 \\
(0.014)\end{array}$ & $\begin{array}{c}0.018 \\
(0.014)\end{array}$ & $\begin{array}{c}0.003 \\
(0.011)\end{array}$ & $\begin{array}{l}-0.011 \\
(0.010)\end{array}$ \\
\hline Treated & $\begin{array}{c}-0.014 \\
(0.074)\end{array}$ & $\begin{array}{l}-0.007 \\
(0.067)\end{array}$ & $\begin{array}{c}0.016 \\
(0.059)\end{array}$ & $\begin{array}{l}-0.042 \\
(0.081)\end{array}$ & $\begin{array}{c}0.046 \\
(0.073)\end{array}$ & $\begin{array}{c}0.004 \\
(0.072)\end{array}$ & $\begin{array}{c}0.014 \\
(0.056)\end{array}$ & $\begin{array}{l}-0.028 \\
(0.069)\end{array}$ \\
\hline Exposure Time (Weeks) & $\begin{array}{c}-0.002 \\
(0.009)\end{array}$ & $\begin{array}{c}0.004 \\
(0.009)\end{array}$ & $\begin{array}{c}0.002 \\
(0.009)\end{array}$ & $\begin{array}{c}0.005 \\
(0.011)\end{array}$ & $\begin{array}{c}0.002 \\
(0.010)\end{array}$ & $\begin{array}{c}0.004 \\
(0.010)\end{array}$ & $\begin{array}{c}-0.003 \\
(0.008)\end{array}$ & $\begin{array}{c}0.010 \\
(0.010)\end{array}$ \\
\hline Observations & 34,506 & 17,945 & 16,463 & 6,536 & 7,595 & 7,585 & 6,974 & 5,718 \\
\hline \multicolumn{9}{|c|}{ B. Reading } \\
\hline \multicolumn{9}{|l|}{ I. Reduced-Form Treatment Effect } \\
\hline Post*Treated & $\begin{array}{c}0.023 \\
(0.053)\end{array}$ & $\begin{array}{c}0.061 \\
(0.067)\end{array}$ & $\begin{array}{l}-0.001 \\
(0.052)\end{array}$ & $\begin{array}{c}0.060 \\
(0.096)\end{array}$ & $\begin{array}{c}0.034 \\
(0.072)\end{array}$ & $\begin{array}{c}0.080 \\
(0.068)\end{array}$ & $\begin{array}{c}0.000 \\
(0.058)\end{array}$ & $\begin{array}{l}-0.033 \\
(0.053)\end{array}$ \\
\hline Treated & $\begin{array}{c}-0.029 \\
(0.056)\end{array}$ & $\begin{array}{c}0.003 \\
(0.055)\end{array}$ & $\begin{array}{c}0.021 \\
(0.047)\end{array}$ & $\begin{array}{c}-0.019 \\
(0.055)\end{array}$ & $\begin{array}{c}0.035 \\
(0.060)\end{array}$ & $\begin{array}{c}0.019 \\
(0.059)\end{array}$ & $\begin{array}{c}0.000 \\
(0.043)\end{array}$ & $\begin{array}{c}0.025 \\
(0.049)\end{array}$ \\
\hline Observations & 34,568 & 18,128 & 16,343 & 6,685 & 7,586 & 7,631 & 6,966 & 5,603 \\
\hline \multicolumn{9}{|c|}{ II. Treatment Effect \& Exposure Time } \\
\hline Post*Treated & $\begin{array}{c}0.070 \\
(0.075)\end{array}$ & $\begin{array}{c}0.113 \\
(0.109)\end{array}$ & $\begin{array}{c}0.090 \\
(0.080)\end{array}$ & $\begin{array}{c}0.198 \\
(0.155)\end{array}$ & $\begin{array}{c}0.022 \\
(0.110)\end{array}$ & $\begin{array}{c}0.108 \\
(0.101)\end{array}$ & $\begin{array}{c}0.113 \\
(0.085)\end{array}$ & $\begin{array}{c}0.062 \\
(0.093)\end{array}$ \\
\hline Post*Exposure Time (Weeks) & $\begin{array}{c}-0.009 \\
(0.010)\end{array}$ & $\begin{array}{l}-0.010 \\
(0.014)\end{array}$ & $\begin{array}{l}-0.017 \\
(0.011)\end{array}$ & $\begin{array}{l}-0.025 \\
(0.022)\end{array}$ & $\begin{array}{c}0.002 \\
(0.014)\end{array}$ & $\begin{array}{c}-0.005 \\
(0.013)\end{array}$ & $\begin{array}{l}-0.021 * \\
(0.013)\end{array}$ & $\begin{array}{l}-0.019 \\
(0.014)\end{array}$ \\
\hline Treated & $\begin{array}{l}-0.018 \\
(0.074)\end{array}$ & $\begin{array}{l}-0.034 \\
(0.068)\end{array}$ & $\begin{array}{c}-0.002 \\
(0.061)\end{array}$ & $\begin{array}{c}-0.072 \\
(0.080)\end{array}$ & $\begin{array}{c}0.003 \\
(0.074)\end{array}$ & $\begin{array}{c}-0.010 \\
(0.073)\end{array}$ & $\begin{array}{c}-0.005 \\
(0.058)\end{array}$ & $\begin{array}{l}-0.030 \\
(0.069)\end{array}$ \\
\hline Exposure Time (Weeks) & $\begin{array}{l}-0.002 \\
(0.009)\end{array}$ & $\begin{array}{c}0.007 \\
(0.009)\end{array}$ & $\begin{array}{c}0.005 \\
(0.009)\end{array}$ & $\begin{array}{c}0.010 \\
(0.010)\end{array}$ & $\begin{array}{c}0.006 \\
(0.010)\end{array}$ & $\begin{array}{c}0.006 \\
(0.010)\end{array}$ & $\begin{array}{c}0.001 \\
(0.008)\end{array}$ & $\begin{array}{c}0.011 \\
(0.010)\end{array}$ \\
\hline Observations & 34,568 & 18,128 & 16,343 & 6,685 & 7,586 & 7,631 & 6,966 & 5,603 \\
\hline
\end{tabular}

Data covers the 2003-04 through 2007-08 academic years. Achievement scores are standardized within grade and year. Due to a change in the scaling procedure in 2009-10 we standarize using raw scores. The "Post" indicator is set equal to one in 2007-08. "Treated" is an indicator for whether a school starts ICB prior to the testing week. Schools treated in week 9 are dropped as this is the 5 th grade testing week and some schools may have postponed the start of ICB for 5th grade students. *, **, and *** denote significance at the $10 \%, 5 \%$ and $1 \%$ levels, respectively. 
Table 6: Tests of Impacts on School Level Exogenous Covariates

\begin{tabular}{|c|c|c|c|c|c|c|c|c|c|c|c|}
\hline & Female & Black & White & Hispanic & $\begin{array}{c}\text { Economic } \\
\text { Disadvantage }\end{array}$ & LEP & At Risk & Gifted & $\begin{array}{c}\text { Special } \\
\text { Ed }\end{array}$ & $\begin{array}{l}\text { Lagged } \\
\text { Math }\end{array}$ & $\begin{array}{l}\text { Lagged } \\
\text { Reading }\end{array}$ \\
\hline & (1) & (2) & (3) & (4) & $(5)$ & $(6)$ & (7) & $(8)$ & (9) & $(10)$ & (11) \\
\hline \multicolumn{12}{|c|}{ A. Mean for All Grades in School } \\
\hline Post*Treated & $\begin{array}{c}0.011 \\
(0.010)\end{array}$ & $\begin{array}{l}-0.006 \\
(0.011)\end{array}$ & $\begin{array}{c}0.002 \\
(0.002)\end{array}$ & $\begin{array}{c}0.001 \\
(0.012)\end{array}$ & $\begin{array}{c}0.003 \\
(0.008)\end{array}$ & $\begin{array}{l}-0.014 \\
(0.016)\end{array}$ & $\begin{array}{l}-0.001 \\
(0.016)\end{array}$ & $\begin{array}{l}-0.008 \\
(0.012)\end{array}$ & $\begin{array}{l}-0.007 \\
(0.009)\end{array}$ & $\begin{array}{l}-0.031 \\
(0.063)\end{array}$ & $\begin{array}{l}-0.031 \\
(0.050)\end{array}$ \\
\hline Treated & $\begin{array}{l}-0.007 \\
(0.006)\end{array}$ & $\begin{array}{c}0.084 \\
(0.079)\end{array}$ & $\begin{array}{l}-0.006 \\
(0.005)\end{array}$ & $\begin{array}{l}-0.047 \\
(0.077)\end{array}$ & $\begin{array}{c}0.031 * * * \\
(0.011)\end{array}$ & $\begin{array}{l}-0.057 \\
(0.054)\end{array}$ & $\begin{array}{l}-0.012 \\
(0.030)\end{array}$ & $\begin{array}{c}-0.048 * * * \\
(0.015)\end{array}$ & $\begin{array}{c}0.023 * * \\
(0.010)\end{array}$ & $\begin{array}{c}-0.095 * \\
(0.048)\end{array}$ & $\begin{array}{l}-0.085^{*} \\
(0.047)\end{array}$ \\
\hline Observations & 612 & 612 & 612 & 612 & 612 & 612 & 612 & 612 & 612 & 607 & 607 \\
\hline \multicolumn{12}{|c|}{ B. Mean for 5th Grade Only } \\
\hline Post*Treated & $\begin{array}{c}0.006 \\
(0.016)\end{array}$ & $\begin{array}{l}-0.011 \\
(0.016)\end{array}$ & $\begin{array}{c}0.004 \\
(0.004)\end{array}$ & $\begin{array}{c}0.004 \\
(0.017)\end{array}$ & $\begin{array}{c}0.006 \\
(0.014)\end{array}$ & $\begin{array}{l}-0.055^{*} \\
(0.030)\end{array}$ & $\begin{array}{l}-0.006 \\
(0.028)\end{array}$ & $\begin{array}{l}-0.024 \\
(0.018)\end{array}$ & $\begin{array}{c}0.000 \\
(0.011)\end{array}$ & $\begin{array}{l}-0.070 \\
(0.059)\end{array}$ & $\begin{array}{l}-0.030 \\
(0.052)\end{array}$ \\
\hline Treated & $\begin{array}{l}-0.003 \\
(0.007)\end{array}$ & $\begin{array}{c}0.087 \\
(0.081)\end{array}$ & $\begin{array}{l}-0.008 \\
(0.006)\end{array}$ & $\begin{array}{l}-0.052 \\
(0.078)\end{array}$ & $\begin{array}{c}0.032 * * * \\
(0.011)\end{array}$ & $\begin{array}{l}-0.023 \\
(0.053)\end{array}$ & $\begin{array}{c}0.027 \\
(0.027)\end{array}$ & $\begin{array}{c}-0.052 * * * \\
(0.018)\end{array}$ & $\begin{array}{c}0.026 * * \\
(0.012)\end{array}$ & $\begin{array}{c}-0.094 * * \\
(0.046)\end{array}$ & $\begin{array}{l}-0.084 * \\
(0.046)\end{array}$ \\
\hline Observations & 599 & 599 & 599 & 599 & 599 & 599 & 599 & 599 & 599 & 599 & 599 \\
\hline
\end{tabular}

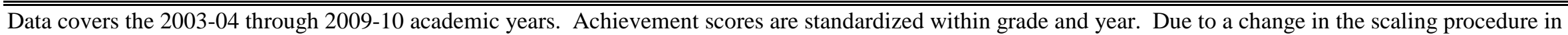

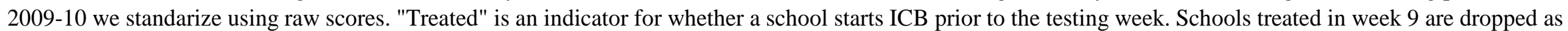
this is the 5 th grade testing week and some schools may have postponed the start of ICB for 5 th grade students. $*, * *$, and $* * *$ denote significance at the $10 \%, 5 \%$ and $1 \%$ levels, respectively. 


\begin{tabular}{|c|c|c|}
\hline & Math & Reading \\
\hline \multicolumn{3}{|l|}{ 1) No Lagged Achievement } \\
\hline Post $*$ Treated & $\begin{array}{c}0.078 \\
(0.060)\end{array}$ & $\begin{array}{l}0.085 * \\
(0.046)\end{array}$ \\
\hline Observations & 44,730 & 44,811 \\
\hline \multicolumn{3}{|l|}{ 2) Exclude Week 5} \\
\hline Post*Treated & $\begin{array}{l}0.095^{*} \\
(0.050)\end{array}$ & $\begin{array}{c}0.097 * * \\
(0.037)\end{array}$ \\
\hline Observations & 34,048 & 34,105 \\
\hline \multicolumn{3}{|l|}{ 3) Exclude Week 2} \\
\hline Post*Treated & $\begin{array}{c}0.097 * * \\
(0.047)\end{array}$ & $\begin{array}{c}0.097 * * \\
(0.037)\end{array}$ \\
\hline Observations & 36,202 & 34,105 \\
\hline \multicolumn{3}{|l|}{ 4) Limit to 2007-08 and Later } \\
\hline Post*Treated & $\begin{array}{c}0.062 \\
(0.052)\end{array}$ & $\begin{array}{c}0.092 * * \\
(0.040)\end{array}$ \\
\hline Observations & 17,236 & 17,298 \\
\hline \multicolumn{3}{|l|}{ 5) No School Fixed Effects } \\
\hline Post*Treated & $\begin{array}{c}0.082 \\
(0.050)\end{array}$ & $\begin{array}{c}0.091 * * \\
(0.037)\end{array}$ \\
\hline Observations & 40,317 & 40,379 \\
\hline \multicolumn{3}{|l|}{ 6) Exposure Time Effect on 4th Grade } \\
\hline Post*Exposure Time (Weeks) & $\begin{array}{c}-0.002 \\
(0.007)\end{array}$ & $\begin{array}{c}0.003 \\
(0.007)\end{array}$ \\
\hline Observations & 43,033 & 43,139 \\
\hline
\end{tabular}

Data covers the 2003-04 through 2009-10 academic years. Achievement scores are standardized within grade and year. Due to a change in the scaling procedure in 2009-10 we standarize using raw scores. "Treated" is an indicator for whether a school starts ICB prior to the testing week. Student level covariates include student's race/ethnicity, gender, and economic status along with year and grade level dummies. School level covariates include percent of students who are white, black, Hispanic, Native American, Asian, economically disadvantaged, LEP, in vocational education, in special education, gifted, in bilingual education, in each grade level, referred to an alternative disciplinary program, and school fixed-effects. *, **, and *** 
Table 8: Effect of In-Class Breakfast on Attendance Rate - Grades 1 to 5 with School Fixed-Effects

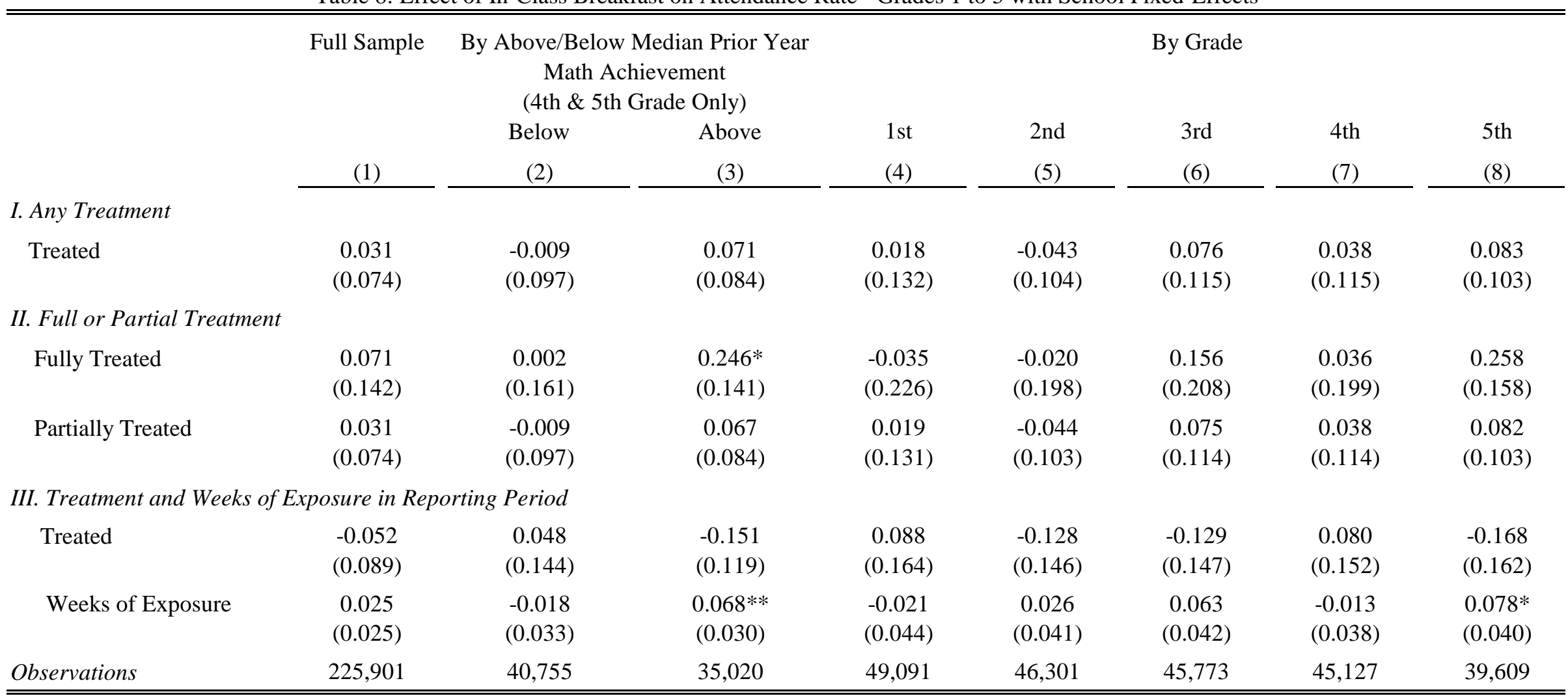

Data covers six reporting periods in 2009-10. Attendance rate is calculated as the number of days present divided by the number of days enrolled during a reporting period. In-class breakfast (ICB) phases in during periods 4, 5 and 6 . "Treated" is an indicator set to one during any period when a student's school of

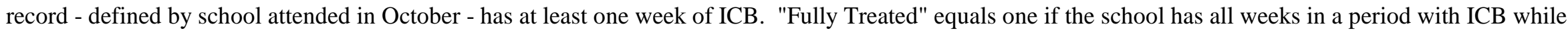
"Partially Treated" equals one if the school has at least one but not all weeks in a period with ICB. "Weeks of Exposure" denote the number of weeks during a reporting period for which a student's school has ICB. Covariates include student's race/ethnicity, gender, and economic status along with reporting period and

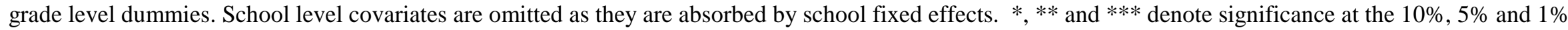
level, respectively. 
Table 9: Effect of In-Class Breakfast on Grades - Grades 1 to 5 with School Fixed-Effects

\begin{tabular}{|c|c|c|c|c|c|c|c|c|}
\hline & Full Sample & $\begin{array}{r}\text { By Above/E } \\
\text { Year Ma } \\
\text { (4th \& } 5\end{array}$ & $\begin{array}{l}\text { Tedian Prior } \\
\text { evement } \\
\text { es Only) }\end{array}$ & & & By Grade & & \\
\hline & $(1)$ & $\begin{array}{c}\text { Below } \\
(2)\end{array}$ & $\begin{array}{c}\text { Above } \\
\text { (3) }\end{array}$ & $\begin{array}{l}1 \mathrm{st} \\
(4)\end{array}$ & $\begin{array}{l}\text { 2nd } \\
(5)\end{array}$ & $\begin{array}{l}3 \mathrm{rd} \\
(6)\end{array}$ & $\begin{array}{l}\text { 4th } \\
(7)\end{array}$ & $\begin{array}{l}5 \text { th } \\
(8)\end{array}$ \\
\hline \multicolumn{9}{|l|}{ I. Any Treatment } \\
\hline Treated & $\begin{array}{c}0.000 \\
(0.031)\end{array}$ & $\begin{array}{c}0.005 \\
(0.053)\end{array}$ & $\begin{array}{l}-0.004 \\
(0.044)\end{array}$ & $\begin{array}{l}-0.017 \\
(0.065)\end{array}$ & $\begin{array}{c}0.004 \\
(0.065)\end{array}$ & $\begin{array}{c}0.031 \\
(0.062)\end{array}$ & $\begin{array}{l}-0.019 \\
(0.065)\end{array}$ & $\begin{array}{c}-0.011 \\
(0.064)\end{array}$ \\
\hline \multicolumn{9}{|c|}{ II. Full or Partial Treatment } \\
\hline Fully Treated & $\begin{array}{c}0.025 \\
(0.056)\end{array}$ & $\begin{array}{c}0.061 \\
(0.093)\end{array}$ & $\begin{array}{l}-0.020 \\
(0.081)\end{array}$ & $\begin{array}{c}0.023 \\
(0.115)\end{array}$ & $\begin{array}{c}0.016 \\
(0.114)\end{array}$ & $\begin{array}{c}0.081 \\
(0.100)\end{array}$ & $\begin{array}{c}0.006 \\
(0.123)\end{array}$ & $\begin{array}{c}-0.022 \\
(0.120)\end{array}$ \\
\hline Partially Treated & $\begin{array}{c}-0.010 \\
(0.024)\end{array}$ & $\begin{array}{c}-0.018 \\
(0.046)\end{array}$ & $\begin{array}{c}0.002 \\
(0.037)\end{array}$ & $\begin{array}{l}-0.034 \\
(0.050)\end{array}$ & $\begin{array}{c}-0.002 \\
(0.050)\end{array}$ & $\begin{array}{c}0.010 \\
(0.052)\end{array}$ & $\begin{array}{l}-0.028 \\
(0.051)\end{array}$ & $\begin{array}{c}-0.007 \\
(0.049)\end{array}$ \\
\hline \multicolumn{9}{|c|}{ III. Treatment and Weeks of Exposure in Grading Period } \\
\hline Treated & $\begin{array}{c}0.038 \\
(0.052)\end{array}$ & $\begin{array}{c}0.070 \\
(0.110)\end{array}$ & $\begin{array}{c}0.097 \\
(0.090)\end{array}$ & $\begin{array}{c}0.024 \\
(0.114)\end{array}$ & $\begin{array}{c}-0.018 \\
(0.097)\end{array}$ & $\begin{array}{c}0.096 \\
(0.098)\end{array}$ & $\begin{array}{c}0.033 \\
(0.126)\end{array}$ & $\begin{array}{c}0.030 \\
(0.101)\end{array}$ \\
\hline Weeks of Exposure & $\begin{array}{l}-0.006 \\
(0.006)\end{array}$ & $\begin{array}{c}-0.011 \\
(0.012)\end{array}$ & $\begin{array}{l}-0.016 \\
(0.010)\end{array}$ & $\begin{array}{l}-0.007 \\
(0.013)\end{array}$ & $\begin{array}{c}0.003 \\
(0.011)\end{array}$ & $\begin{array}{l}-0.010 \\
(0.011)\end{array}$ & $\begin{array}{l}-0.008 \\
(0.014)\end{array}$ & $\begin{array}{l}-0.007 \\
(0.011)\end{array}$ \\
\hline Observations & 286,105 & 51,040 & 44,807 & 62,408 & 59,004 & 58,713 & 55,718 & 50,262 \\
\hline
\end{tabular}

Data covers eight grading periods in 2008-09 and 2009-10. Grades are calculated as the mean numerical grade (on a scale of 50 to 100) over all courses. Inclass breakfast (ICB) phases in during periods 7 and 8. "Treated" is an indicator set to one during any period when a student's school of record - defined by school attended in October - has at least one week of ICB. "Fully Treated" equals one if the school has all weeks in a period with ICB while "Partially Treated" equals one if the school has at least one but not all weeks in a period with ICB. "Weeks of Exposure" denote the number of weeks during a grading period for which a student's school has ICB. Covariates include student's race/ethnicity, gender, and economic status along with grading period and grade level dummies. School level covariates include percent of students who are white, black, Hispanic, Native American, Asian, economically disadvantaged, LEP, in vocational education, in special education, gifted, in bilingual education, in each grade level, referred to an alternative disciplinary program, and school fixed-effects. $*, * *$ and $* * *$ denote significance at the $10 \%, 5 \%$ and $1 \%$ level, respectively. 